\title{
Capital Inflows and Property Prices: Ethnicity, Education, and Spillovers
}

\author{
Yuk-Ying Chang \\ Massey University, Massey Business School \\ y.chang@massey.ac.nz \\ Sudipto Dasgupta (1D) \\ Chinese University of Hong Kong, CUHK Business School \\ s.dasgupta@cuhk.edu.hk (corresponding author)
}

\section{Abstract}

China has experienced significant capital flight over the past two decades. Despite anecdotal evidence that some of this capital has been invested in foreign residential markets, not much is known about its destination and impact. We examine the effects of capital inflows from China on residential property prices and the real economy in the USA and global metropolitan areas. We show that inflows had significant effects on residential property markets and employment in regions that i) have strong ethnic ties to China and ii) are destinations of Chinese students. We document spillovers to geographically adjacent regions without strong Chinese links.

\section{Introduction}

Over the past five decades, flows of capital and people across borders have occurred at a faster pace than ever before. The USA and several European countries have been major destinations of both capital and labor from the developing economies, especially from Asia. The ethnic map of the developed world has changed rapidly, and asset ownership has also changed in tandem.

Residential property is one of the main asset classes that changes ownership when the outflow of capital follows that of labor. Surprisingly, evidence on the significance and determinants of capital inflows from the developing economies on the residential property markets of the developed world has been scarce. An exception is a recent paper by Badarinza and Ramadorai (2018), who examine the effect of increase in political risk in other countries on property prices in the city of London. They find that increase in political risk in a particular country is associated with increases in property prices in areas of London with a high concentration of residents who have ethnic ties to that country. ${ }^{1}$

We thank Cristian Badarinza (the referee) and Jennifer Conrad (the editor) for very helpful comments and suggestions that greatly improved the article. We also thank Sheridan Titman for his helpful discussions. All errors are the authors' own. Chang thanks Massey University's Business Impactful Research Fund for funding.

${ }^{1}$ Based on cash transaction data over the period 2001-2013, Li, Shen, and Zhang (2020) report significant increases in housing prices and employment in ZIP codes in California with high Chinese population over the period 2007-2013, driven by foreign Chinese housing purchases. 
In this article, we examine the effects of capital flight from China - the largest capital-exporting developing country over the past two decades (Kar and LeBlanc (2013)) - on residential housing prices and the real economy, in the USA as well as major global cities. ${ }^{2}$ Our analysis builds on that of Badarinza and Ramadorai (2018) by highlighting not only the importance of ethnic ties to China as a determinant of a region's exposure to Chinese political risk and the associated capital flight, but also the role of educational ties. To the best of our knowledge, ours is the first paper to examine these effects on property prices at international student destinations. ${ }^{3}$ In addition, because we consider a large country like the USA, we are also able to show that there are significant spillover effects on property prices in adjacent regions that have no recorded Chinese residents. Finally, we demonstrate that Chinese capital inflows also affect the real economy by creating employment growth and savings growth in regions with a high Chinese population and international student links with China.

Although it is difficult to obtain accurate data on China's capital outflows (Cheung, Steinkamp, and Westermann (2016), Wong (2017), and Taplin (2019)), several papers argue that the outflows have been increasing and are significant (see Gunter (2017), Wong (2017)). Gunter (2017) estimates that capital flight from China in 2014 was equivalent to $17 \%$ of its exports, almost twice its current account balance, and $165 \%$ of inward foreign direct investment (FDI) that year. It also exceeded inward FDI every year in the past decade.

Anecdotal evidence and industry and media reports indicate that foreign housing markets are important destinations of Chinese capital flight. However, the extent of the impact on the U.S. property market remains unclear. First, it is possible that any impact, if present, is largely limited to the West Coast. ${ }^{4}$ Second, the quantitative importance is unclear. According to the National Association of Realtors, while Chinese foreign buyers were the top buyers in terms of both volume and number, ${ }^{5}$ accounting for $20 \%$ of the total foreign buyer volume, the dollar volume of all foreign purchases in the USA accounted for $10 \%$ of existing home sales in 2016-2017. ${ }^{6}$ These numbers suggest, at best, a modest impact of Chinese investment in the U.S. residential market. Therefore, the quantitative significance of Chinese residential investment for the overall U.S. residential market remains an empirical question.

\footnotetext{
${ }^{2}$ The terms "capital outflow" and "capital flight" are used interchangeably in the rest of this article. While the broad concept is similar, capital flight has been defined in alternative ways by researchers. One such definition is “. . an outflow of funds from a country motivated by an adverse change in the country's economic, political or social environment” (Gunter (2008), p. 434), which is essentially capital flight.

${ }^{3}$ Yang (2022) finds that banks more recognized by Chinese university students experience more deposit growth associated with the influx of Chinese students, and these banks increase credit supply to local small business borrowers and second lien mortgagors in the U.S. She also documents that counties with more Chinese students have higher employment and more establishments in the same state-year.

${ }^{4}$ According to the National Association of Realtors, one third of Chinese residential investment in 2016-2017 was in California.

${ }^{5}$ China overtook Canada as the top foreign country investing in U.S. residential real estate in 2014-2015.

${ }^{6}$ These figures classify only nonresident individuals and those who have been residents in the USA for less than 2 years (including temporary visa holders) as foreign buyers.
} 
Although some estimates of capital outflows from China are available, it is challenging to obtain estimates of Chinese capital inflows to specific regions, even at the country-level. This makes it problematic to relate inflows to housing price changes in U.S. Metropolitan Statistical Areas (MSAs) or in global cities. To circumvent this problem, we adopt several strategies, based on Badarinza and Ramadorai's (2018) observation of "political flight to safety" associated with ethnic links. First, we identify two instances, in 1997 and 2011, of significant capital flight from China associated with an increased perception of political risk in that country. The 1997 episode is the death of Deng Xiaoping in 1997. The 2011 episode is the bursting of the Chinese property market bubble and Xi Jinping's anti-corruption campaign (launched in 2012). ${ }^{7}$ Figure 1 shows a modest surge of Chinese capital outflows after 1997 and a substantial surge after 2011. Figure 2 shows the ratio of an index of China's political risk to that of the USA peaks after 1997 and again increases after 2011. We argue that regions with stronger ethnic ties to China would attract significantly higher capital inflows from China after these events than before, compared to regions with weaker ethnic ties. Thus, we compare, in a difference-indifferences setting, residential property price growth in regions having stronger Chinese ties with those having weaker Chinese ties over 5-year periods before and after the two major instances.

Second, we use the annual measure of relative political risk (RPR) of China and the USA in "reduced form" regressions as a possible instrument for Chinese

FIGURE 1

5-Year Moving Average Chinese Capital Flight

Figure 1 shows the 5 -year moving averages of three estimates of Chinese capital flight, following methods discussed in Gunter (2017): Gunter's adjusted balance of payments (BOP) estimate based on Cuddington (1986) in dark gray, Cuddington's BOP estimate in light gray, and an estimate based on the BOP balancing entry "net errors and omissions" in black.

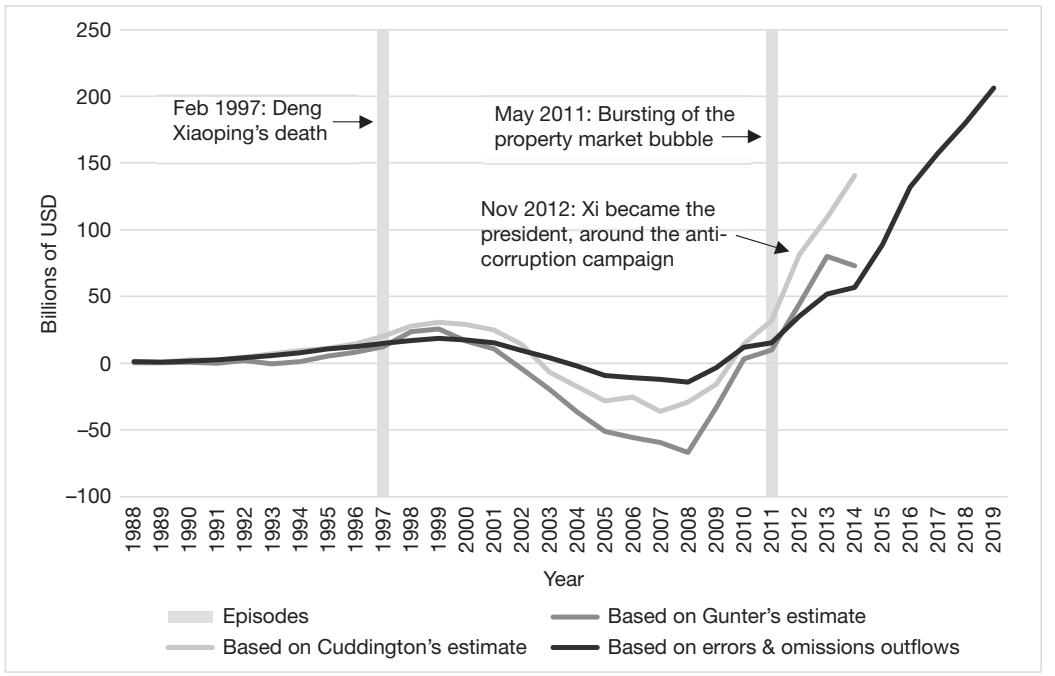

${ }^{7}$ See Gunter (2004), Zhu, Li, and Epstein (2005), Cheung and Qian (2010), and Gunter (2017). Kar and Spanjers (2014) indicate that China registered a particularly large increase in capital outflow in 2011 (\$162.8 billion) and 2012 (\$249.6 billion). 
In Figure 2, the U.S.-China reported trade value gap data (CINFC) for the period 1995-2008 (large shaded rectangle) is from Ferrantino, Liu, and Wang (2012). The CINFC estimates outside the rectangle are based on 100 imputed data sets and the assumption that China's political risk relative to the USA (RPR) and CINFC follow a joint multivariate normal distribution. Multiple imputations consider uncertainty around the true value of the missing data and generate several different plausible imputed data sets in reproducing the variance/covariance matrix we would have observed had our data not been missing. Each imputed CINFC value is the sum of a value associated with RPR and a random component whose magnitude shows the degree of uncertainty. The method of multiple imputations is outlined in https://www.stata.com/bookstore/multiple-imputationreference-manual/. The dotted lines are 5-year moving averages of the solid lines of the same color.

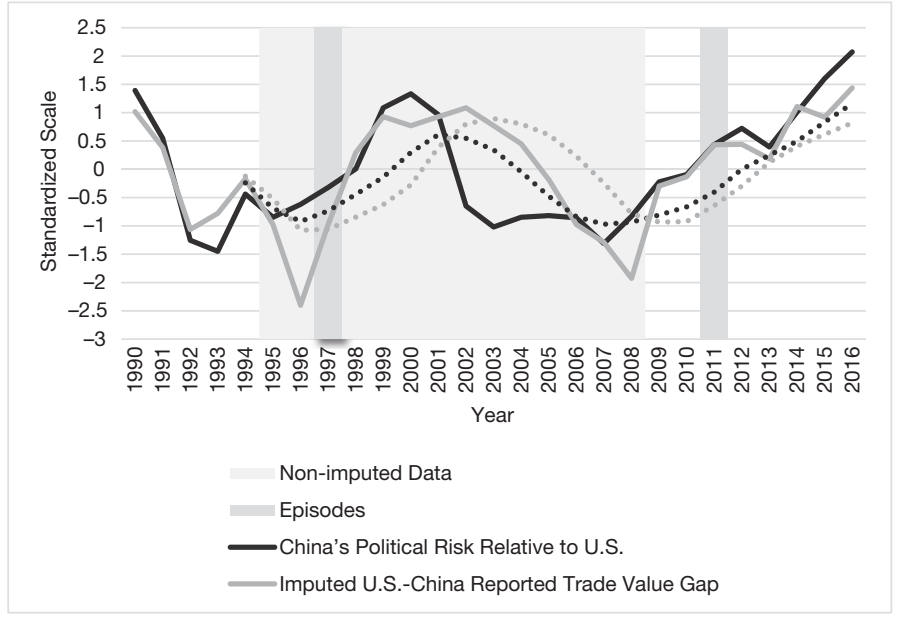

capital inflow to the USA (CINFC) and examine whether regions with stronger ethnic ties to China experience higher appreciation in residential property prices when RPR is higher. The RPR series can be constructed for 1985-2016. To validate the premise that RPR is a determinant of CINFC, we take advantage of a relatively short time series of estimated CINFC from Ferrantino, Liu, and Wang (2012) which is available for 1995-2008. We find that the two series are highly correlated (with a correlation coefficient of 0.53 ), shown in Figure 2, and both the index of China's political risk as well as that of the USA separately explain annual variation in CINFC. Finally, we also create a series of "imputed CINFC" using the method of multiple imputations based on RPR and use this variable to capture Chinese capital flight to the USA during 1990-2016. We validate our main results using the imputed CINFC series as a measure of capital inflow from China to the USA.

In our analysis of the impact of Chinese capital inflows on housing prices in the USA, the strength of Chinese ties in different regions is proxied by the recorded Chinese population in these regions as of 1870 or 1880 . We rely on historical Chinese population distribution to address the concern that the regions with higher Chinese populations during our period of study may not be randomly assigned. It is possible that these regions have economic characteristics that caused housing prices to grow faster, especially in a period when housing prices are recovering or generally rising. We argue that our classification based on the early Chinese population mitigates this concern because these early distribution 
patterns persist over time ${ }^{8}$ for reasons that are less relevant for current economic prospects of these regions. ${ }^{9}$ We also verify that prior to the two events, the economic characteristics of the regions with high and low Chinese populations are generally similar. In our regressions, we also control for MSA, county, or MSA $\times$ year fixed effects. In addition, we include in our regressions several control variables that vary over time to minimize the omitted variable problem. Finally, we repeat our tests by excluding the top $10 \%$ of MSAs in terms of recent Chinese population distribution, and by excluding California completely.

Overall, our results show significantly stronger effects of CINFC on U.S. residential housing prices in regions with a high Chinese concentration than those with a low Chinese concentration. We also document significantly stronger spillover effects of Chinese capital inflows to the USA to counties that have no recorded Chinese in states with higher Chinese population (that are likely to attract more Chinese capital inflow). The spillover effects decay as these counties' distance from the most densely Chinese-populated county in the same state increases.

We examine the real economic effects of CINFC. Following the same approach as that for our study of residential property prices above, we also find significantly stronger effects of Chinese capital flights on U.S. employment and deposit growth in regions with high Chinese concentration than in those with low Chinese concentration.

Next, we examine the possible effects of educational links, particularly the widely reported phenomenon that many Chinese parents invest in residential property when their children move to another country to study. We use crosssectional data (as of 2017) on the number of international students in each state to classify states as among the top third of states and bottom third of states in terms of student destinations. We find that for the top third hosting states, the change in the annual number of Chinese international students has a significantly larger positive effect on the difference in property price growth between greater and lesser Chinese-populated MSAs in the same state for the period 2000-2016. There are no effects for the bottom third hosting states. We further find that such effects are stronger in the post-event period than that in the pre-event period. This suggests that it is not only the inflow of students but inflow of more capital per student that drives property prices in the Chinese-populated MSAs of these top hosting states. We find no such effects associated with non-Chinese international students.

Finally, we extend our analysis to global metropolitan areas. Due to data limitations, we have to pursue a somewhat different estimation strategy and limit

\footnotetext{
${ }^{8}$ The correlation of county-level Chinese population in 1870 and that in 2000 and 2010 is 0.38 and 0.34 , respectively. We provide further details in Section III.C.

${ }^{9} \mathrm{We}$ do not claim that early Chinese population distribution over different regions is random. It is possible that any early population distribution is determined by regional characteristics that persist over long periods and potentially bias our results. However, we show that when regions are classified as highly or sparsely populated based on early overall U.S. population distribution, we do not get results similar to those for classifications based on Chinese population. Thus, for our results to be attributable to nonrandom selection, the regional characteristics would have to be relevant not for human settlement in general, but only for early Chinese settlement, and persist for long periods. We also show that proximity to coastal areas (where significant early Chinese settlement occurred and which have thrived economically) does not explain our results.
} 
attention to the 2011 episode and the sample period since 2000. In particular, we use Chinese population (student) inflows (as a proportion of total population (student) inflows) to a particular country in a particular year as an indicator of the likely destination of Chinese capital. We find that Chinese population (student) inflows are more strongly associated with changes in residential prices and employment when CINFC is higher.

Our article makes several contributions. First, we show that ethnic ties between China and other regions have been important determinants of the destination of capital outflows from China. Capital flight associated with greater political uncertainty in China can have a nontrivial impact on residential prices in the destination regions, and can also have real economic consequences by affecting employment growth and bank deposit growth in these regions. Overall, these results shed light on the question of the quantitative importance of Chinese capital inflows and investment in real estate for U.S. residential property markets. Second, using educational migration patterns for identification, we confirm the relevance of pure capital transfers as a transmission channel, above and beyond the role of population movement. Finally, we study the effects of capital flight from China to other nonU.S. destinations and find similar effects on residential prices and employment.

The rest of the article is organized as follows: Section II discusses our data, defines the key variables, and provides some descriptive statistics. Section III outlines our empirical methodology. Sections IV-VII present our main results, and Section VIII discusses some additional tests on the robustness of our results. Section IX concludes.

\section{Data, Descriptions, and Key Variables}

We exploit variation in the geographical distribution of the Chinese population in the USA for our identification strategy. We obtain population data from the U.S. Census and the U.S. Bureau of Economic Analysis. We principally use data on early Chinese settlement in the USA, available for the years 1870 (U.S. counties) and 1880 (U.S. states). Some of our tests require data on more recent Chinese population distribution, for which we use data as of the year 2010 .

For global city-level analysis, we do not have comparable Chinese population data. However, we obtain data on annual Chinese and total population inflows to the corresponding countries from the Organisation for Economic Cooperation and Development (OECD) for 2000-2017. List 5 in Table OA1 of the Supplementary Material provides the list of cities constituting the sample for the analysis of Chinese population inflows and global city housing price growth.

Real or nominal housing price growth is one of the main dependent variables in our study. ${ }^{10}$ We examine this at the MSA and county levels. We construct a time series of quarterly real housing price growth at the MSA level from the Freddie Mac MSA Real Housing Price Index of Global Financial Data. We estimate the annual nominal housing price growth of counties based on the annual House Price Index of the counties downloaded from the website of the U.S. Federal Housing Finance

\footnotetext{
${ }^{10}$ All growth variables are winsorized at the $1 \%$ and $99 \%$ to minimize the influence of outliers and errors in the data.
} 
Agency (FHFA; https:/www.fhfa.gov/DataTools/Downloads/Pages/House-PriceIndex-Datasets.aspx).

Our tests also require various economic variables at the state, MSA, and county levels. We source personal income, employment, and labor data from the data website of the U.S. Bureau of Economic Analysis (https://www.bea.gov/data) and the statistics website of the U.S. Bureau of Labor Statistics (https://www.bls. gov/data/). We calculate the quarterly deposit growth of the MSAs based on the deposit data of FFIEC CDR (Central Data Repository) Call Bulk Schedule of the U.S. Federal Financial Institutions Examination Council (FFIEC) (https://www. fhfa.gov/DataTools/Downloads/Pages/House-Price-Index-Datasets.aspx). However, the deposit data is available only from the year 2001. To match the real housing price growth of the MSAs, we obtain MSA deflators to convert nominal personal income to real personal income.

Our quarterly housing price growth data for major cities around the world are based on the housing price indices of these cities, complied by the Knight Frank Group. For global metropolitan areas, we obtain the employment data from the OECD. GDP data for the countries in which these cities are located are obtained from Datastream.

We use China's political risk relative to the USA or another country (RPR or $\mathrm{RPR}_{c}$ ) as a determinant of the capital flight from China to the USA or another country. We use the International Country Risk Guide (ICRG) indexes of political risk ratings of China, the USA, and other countries from the PRS Group.

As education is a frequently mentioned consideration for Chinese overseas property purchases, we study whether the capital inflows from China have a more important effect on housing prices in regions that attract more foreign students. We obtain the number of tertiary international students in each U.S. state (as of 2017) from the website of the Institute of International Education (IIE). ${ }^{11}$ List 4 in Table OA1 of the Supplementary Material presents the number of tertiary international students by states. The top 3 states are California, New York, and Texas. The list also indicates which of these states do not have any of the top Chinese-populated MSAs in List 2 of Table OA1. Among these latter states, the top 3 hosting states are Ohio, Michigan, and Missouri. Except for Texas, Chinese students account for about $30 \%-40 \%$ of international students in each of these top hosting states. We also obtain time series of the numbers of total and Chinese international students for the countries with the city housing data from the UNESCO (United Nations Educational, Scientific, and Cultural Organization) Institute of Statistics. List 6 in Table OA1 indicates cities comprising the sample for our analysis of Chinese student inflows and global housing price growth.

\section{Empirical Methodology}

As argued in Badarinza and Ramadorai (2018), ethnic links are likely to be a significant determinant of destinations of capital outflows, especially for residential

\footnotetext{
${ }^{11}$ IIE previously provided state fact sheets that could be downloaded from its Open Doors data website. However, such state fact sheets are no longer available. Instead, IIE provides fast fact sheets that show the top 10 states hosting international students each year over 2010-2020. https://opendoorsdata. org/fast_facts/fast-facts-2020/. Retrieved Jan. 21, 2021.
} 
property investment, for a number of reasons. First, social links with relatives, friends, or friends of friends are likely to be important in mitigating information asymmetries, e.g., general information about the local property market, or locating realtors and lawyers who speak the language of the buyers and understand their requirements. Second, socially connected individuals can also perform an important monitoring role, essentially "looking after" the property or screening and monitoring tenants if the property is rented out. Third, as documented by Agarwal, Choi, He, and Sing (2019), ethnicity-specialized real estate agents can also facilitate sales of residential units at a later point in time.

\section{A. Identifying CINFC}

Estimates of capital flight from China to specific destinations are not available for long time periods. For inflows to the USA, Ferrantino et al. (2012) provide estimates for 1995-2008 based on the idea that capital flight from China to the USA is reflected in the under-invoicing of Chinese exports to the USA or over-invoicing of U.S. imports from China. We extend this time series using the method of multiple imputations, based on the series for RPR which is available for 1985-2016. Figure 2 shows both standardized time series (solid lines) and the 5-year moving average for each series (dotted lines). ${ }^{12}$ The two series exhibit significant correlation for 1995-2008 (the large shaded rectangle in the figure), a period for which we have estimates from Ferrantino et al. (2012) for CINCF. The correlation is consistent with the idea that capital flight is motivated by an increase in perceived relative political risk (Badarinza and Ramadorai (2018)). The two moving average series also move closely together, with the series for RPR slightly leading the series for CINCF. When we regress CINFC on RPR for the period 1995-2008, we get a positive coefficient on RPR of 0.37 (significant at the $1 \%$ level), with an $R^{2}$ of $28 \%$. Ferrantino et al. (2012) also suggest that the first-differenced CINFC captures capital flight from China to the USA after removing time trends in mis-invoicing. When we regress the first difference of CINFC on RPR, the coefficient on the latter is 0.50 (significant at the $1 \%$ level) and a regression $R^{2}$ of $48 \%$.

We use RPR as a proxy for CINFC in reduced-form regressions as part of our empirical design. We also create a measure of change in relative political risk by subtracting from RPR its past-3-year average (DRPR). Our reduced-form results are qualitatively similar but less significant when we use this variable instead of RPR. However, a dummy variable that equals 1 when DRPR is above the 90th percentile produces significant results in our reduced-form specifications. ${ }^{13}$

\section{B. Two Trigger Events}

Estimates of capital flight from China (but not specific to any particular destination) are available for 1984-2014 from Gunter (2017), who provides three estimates of Chinese capital flight. Figure 1, reproduced and extended following methods discussed in Gunter (2017), shows the 5-year moving averages of three

\footnotetext{
${ }^{12}$ Outside the shaded area, CINCF is generated based on the method of multiple imputation using RPR.

${ }^{13}$ Badarinza and Ramadorai (2018) also use the 90th percentile as their cut-off.
} 
estimates: Gunter's adjusted balance of payments (BOP) estimate based on Cuddington (1986), Cuddington's BOP estimate, and an estimate based on the BOP balancing entry "net errors and omissions." 14

Even though these estimates are not specific to the USA or any particular country, it is quite evident that capital flight from China accelerated modestly after 1997 and again more significantly after 2011. In Figure 2, it can also be seen that these episodes of surges in capital outflow coincided with corresponding increases in RPR. In both instances, the increase in RPR is driven by the numerator (i.e., China's political risk). One can relate both episodes to events in China that appear exogenous to the external economies for which we study the impact of these surges in capital outflows. The 1997 episode occurred immediately after Deng Xiaoping's death in the first quarter of that year, and the 2011 episode occurred after the bursting of the Chinese property bubble (second quarter in 2011) and the subsequent launch of the anti-corruption drive in China (fourth quarter of 2012). Gunter (2017) links the post-2011 capital flight to the anti-corruption campaign, a sharp increase in income inequality in China, lower transaction costs, and a desire to migrate for educational, economic, political, social, or environmental reasons (see Gunter (2017), Section 6), which may have been triggered by a softening of capital controls after 2009 to internationalize the renminbi (RMB).

We argue that even though capital flight to the USA or any specific destination cannot be accurately measured, capital inflow from China to the regions with strong ethnic ties to China is likely to have significantly increased during these episodes. In our empirical analysis, we focus on 5-year periods immediately before and after the two episodes. For ease of discussion, we refer to the years 1997 and 2011 (1997: Q1 and 2011:Q2) as "event years" ("event quarters") associated with the start of each of the two episodes of increased capital outflows. ${ }^{15}$

\section{Empirical Strategy}

For the USA, we have Chinese population settlement data as early as 1870 for counties and 1880 for states. ${ }^{16}$ We use this early settlement data to determine regions with strong ethnic ties and weak ethnic ties to China. Similar classifications based on more recent data could correlate with regional characteristics that attract both the Chinese population and increase property prices and thereby biasing our results. Drawing on early settlement data mitigates this concern. We provide evidence below that these early Chinese population distribution patterns are fairly persistent, and the regions classified as having stronger ethnic ties to China have

\footnotetext{
${ }^{14}$ Cuddington's (1986) method essentially defines capital flight as "hot money" that leaves the country in response to perceived small changes in risk or return, and is calculated as the sum of shortterm capital exports by the nonbank sector and errors and omissions (the balancing entry, which is supposed to reflect unrecorded short-term capital flows). Gunter (2017) further adjusts Cuddington's estimate by subtracting the change in foreign financial assets held by residents in China, reported by People's Bank of China. See Gunter (2017) for details.

${ }^{15}$ These 2 years (quarters) are excluded from our empirical analysis. Our results are also robust to defining the launch of the anti-corruption drive as the relevant event for the second episode.

${ }^{16}$ We have 1870 county Chinese population data for $62 \%$ of the states. Therefore, we do not aggregate 1870 county Chinese numbers to estimate state Chinese numbers.
} 
significantly more Chinese population, both in numbers and in terms of percentage of Chinese, as of the year 2010.

For the two events of 1997 and 2011, our empirical strategy is to examine whether the regional housing price growth is higher in the 5-year period immediately after each of the events compared to the 5-year period immediately before, for regions that have stronger ethnic ties to China compared with those that have weaker ties.

We conduct our analysis both at the level of MSAs as well as counties. For MSAs, we utilize quarterly data on housing prices, while for counties our data is at an annual frequency. When the analysis is done at the MSA level, we use MSA fixed effects and cluster standard errors by quarter.

For counties, we conduct three types of analysis. Similar to our regressions at the MSA level, we run regressions at the county level using county fixed effects and cluster standard errors by year. For regressions involving within-MSA comparisons between counties with stronger and weaker Chinese ethnic ties, we incorporate MSA $\times$ year fixed effects and cluster standard errors at the state level. For our analysis of spillover effects of Chinese capital inflows, our unit of analysis is a county without any recorded Chinese population as of the year 2010. Here, we use county and year fixed effects, and cluster standard errors by state.

Thus, our empirical specifications take the following form:

$$
\mathrm{HPG}_{\mathrm{jt}}=a+b \times \mathrm{POST}+c \times \mathrm{HCT}_{\mathrm{jt}} \times \mathrm{POST}+d \times X_{\mathrm{jt}}+\mathrm{FE}+\epsilon_{\mathrm{jt}},
$$

where subscripts $j$ and $t$ index region and time, respectively. The dependent variable is the housing price growth (HPG) per quarter or per year. POST is an indicator variable that has a value of 1 if the unit of observation occurs in the 5-year window after the event, and a value of 0 if it occurs in the 5-year window before the event. $\mathrm{HCT}$ is an indicator variable that has a value of 1 if the unit of observation pertains to a region that is considered to have stronger ethnic ties to China, and a value of 0 if the region is considered to have weaker ethnic ties to China.

For our reduced-form regressions, we replace POST with lagged RPR. The sample period is 1986:Q1-2016:Q4 for MSA-level analysis and 1986-2016 for country-level analysis.

$$
\mathrm{HPG}_{\mathrm{jt}}=a+b \times \mathrm{RPR}_{t-1}+c \times \mathrm{HCT} \times \mathrm{RPR}_{t-1}+d \times \mathrm{X}_{j t}+\mathrm{FE}+\epsilon_{j t}
$$

We next discuss how the HCT dummy is constructed. For MSA-level analysis, we assign to each MSA the Chinese population number in its state as of 1880. MSAs that are in the top quartile of the resulting distribution are classified as MSAs with strong ethnic ties to China $(\mathrm{HCT}=1)$, whereas those in the bottom quartile are classified as having weak ties to China $(\mathrm{HCT}=0) .{ }^{17}$ As shown in Panel A of Table 1, the Chinese population distribution is quite persistent over time. Using MSA-level Chinese population data for the year 2010, we find that the mean Chinese population number in HCT $=1$ MSAs was 17,784 and the Chinese population percentage was $0.7 \%$, and the corresponding numbers for $\mathrm{HCT}=0$ MSAs were 2,501 and $0.2 \%$, respectively.

\footnotetext{
${ }^{17}$ For states with an MSA at the margin of the 75th (25th) percentile threshold, all MSAs are included in $\mathrm{HCT}=1(\mathrm{HCT}=0)$ groups.
} 
TABLE 1

\section{Pre-Event Characteristics of High and Low Chinese-Populated MSAs and Counties}

Table 1 compares the mean statistics of HIGH_CHINESE $(H C T=1)$ and LOW_CHINESE $(H C T=0)$ counties and MSAs in our regression samples of Tables 2 and 7 for the years 1996 and 2010 (i.e., immediately before the 1997 and 2011 events, respectively). ${ }^{* \star},{ }^{* *}$, and ${ }^{*}$ indicate a statistically higher mean of a 2-sided $t$-test of the null hypothesis that the means of HIGH_CHINESE and LOW_CHINESE counties/MSAs are the same, at the $1 \%, 5 \%$, and $10 \%$ level of significance, respectively.

\begin{tabular}{|c|c|c|c|c|}
\hline & $\begin{array}{c}\text { MSAs } \\
(1)\end{array}$ & $\begin{array}{c}\text { MSAs } \\
(2) \\
\end{array}$ & $\begin{array}{c}\text { Counties } \\
\text { (3) } \\
\end{array}$ & $\begin{array}{c}\text { Counties } \\
(4) \\
\end{array}$ \\
\hline Year & 2010 & 1996 & 2010 & 1996 \\
\hline
\end{tabular}

Panel A. Chinese Population

\section{$\underline{ }$}

HIGH_CHINESE

LOW_CHINESE

HIGH_CHINESE

LOW_CHINESE

2010 Chinese Population

\begin{tabular}{cc}
$17,784^{*}$ & $\begin{array}{c}47,505^{\star *} \\
6,109\end{array}$ \\
2,501 & $3.9^{\star \star}$ \\
\hline $0.7^{\star \star}$ & 0.7
\end{tabular}

$\underline{\text { Panel B. Key Economic Characteristics }}$

HIGH_CHINESE

LOW_CHINESE

HIGH_CHINESE

LOW_CHINESE

HIGH_CHINESE

LOW_CHINESE

HIGH_CHINESE

LOW_CHINESE

HIGH_CHINESE

LOW_CHINESE

HIGH_CHINESE

LOW_CHINESE

HIGH_CHINESE

LOW_CHINESE

HIGH_CHINESE

LOW_CHINESE

\begin{tabular}{cccc}
\multicolumn{4}{c}{ Personal Income per Capita (dollars) } \\
\hline 36,372 & 22,370 & 50,510 & 27,085 \\
35,363 & 21,986 & 44,447 & 26,417 \\
& Growth of Personal Income per Capita \\
\hline 0.0185 & 0.0428 & 0.0308 & 0.0561 \\
0.0183 & 0.0439 & 0.0266 & 0.0634 \\
& Labor-to-Population Ratio & \\
\hline 0.4916 & 0.4945 & 0.5148 & 0.4937 \\
0.4875 & 0.5064 & 0.5123 & $0.5169^{*}$ \\
& Growth of Labor-to-Population Ratio & \\
\hline-0.0156 & -0.0002 & 0.0071 & 0.0037 \\
-0.0125 & $0.0063^{\star * *}$ & -0.0078 & 0.0029 \\
& Employment-to-Population Ratio & \\
\hline 0.4399 & 0.4601 & 0.4627 & 0.4634 \\
0.4428 & 0.4837 & 0.4668 & $0.4915^{*}$ \\
& Growth of Employment-to-Population Ratio & \\
\hline-0.0262 & 0.0026 & 0.0010 & 0.0062 \\
-0.0157 & $0.0081^{\star *}$ & -0.0133 & 0.0060 \\
& Bank Deposits per Capita (thousands of dollars) & \\
\hline 9.93 & - & 84.32 & - \\
17.77 & - & 49.53 & - \\
& Growth of Bank Deposits per Capita & - \\
\hline-0.0521 & - & -0.0029 & - \\
-0.0337 & - & 0.0266 &
\end{tabular}

For our within-MSA county-level analysis, counties in the same MSA are classified as having stronger $(\mathrm{HCT}=1)$ ethnic ties to China if they are above the MSA median in terms of the number of Chinese in the county as of the year 1870. The remaining counties are classified as having weaker $(\mathrm{HCT}=0)$ ethnic ties to China. ${ }^{18}$ The data shows remarkable persistence in terms of the distribution of Chinese population across counties from 1870 to 2010. As indicated in Panel A of Table 1, as of 2010, the mean number of Chinese in the HCT $=1$ counties was 47,505 and the mean Chinese population percentage was 3.9\%, compared to 6,109 and $0.7 \%$, respectively, in the HCT $=0$ counties. Finally, for our analysis of the

\footnotetext{
${ }^{18}$ Since many counties are without any recorded Chinese population as of 1870 , the median is based on counties with Chinese population. The "below-median" counties are pooled with the counties without any recorded population in the $\mathrm{HCT}=0$ group because many of these have very small Chinese population numbers.
} 
spillover effect of CINFC to counties without any recorded Chinese population as of 2010, HCT $=1$ if the state had above-median Chinese population (in terms of number or proportion), and HCT $=0$ otherwise.

We check whether the regions classified as HCT $=1$ and HCT $=0$ differ, prior to the two events of 1997 and 2011, in terms of key economic characteristics. Panel B of Table 1 gives a list of the characteristics as of the year before each event, as well as the statistically significant $p$-values for the pairwise comparison of subsample means. The $p$-values indicate that the subsamples are homogeneous with respect to most of the characteristics. The only exceptions are that HCT $=0 \mathrm{MSAs}$ experience higher growth of labor per capita and employment per capita and the HCT $=0$ counties have higher labor per capita and employment per capita in 1996 (prior to the first event). To the extent that these differences suggest more robust economic activity in the regions with weaker Chinese ties, they are unlikely to explain our results.

Finally, to further ensure that our results are not due to differences in regional demographic or economic prospects between greater and lesser Chinese-populated regions, in addition to region or region interacted with year fixed effects, we include many time-varying control variables, such as contemporaneous per capita income growth, contemporaneous population growth, rolling past 5-year regional income growth, and future average income growth and population growth.

\section{MSA-Level Results: Chinese Capital Inflow, Housing Prices, and Real Activity}

\section{A. MSA-Level Quarterly Housing Price Growth}

Our first set of results is from regressions where the dependent variable is quarterly housing price growth at the MSA level. The high Chinese population dummy HCT has a value of 1 if the MSA is in the highest quartile, and a value of 0 if it is in the lowest quartile. MSAs that are in the two middle quartiles are excluded. List 1 in Table OA1 of the Supplementary Material shows the states that contain the MSAs in the top (Panel A) and bottom (Panel B) quartiles.

The results for the two events are reported in columns 1 and 2 of Table 2. We find that the residential prices in the MSAs with high state-level Chinese population (as of 1880) increased about $1.1 \%$ more per quarter after the 2011 event than those with low state-level Chinese population. This effect therefore is economically highly significant. ${ }^{19}$ The economic magnitude of the same effect after the 1997 event is smaller: about $0.4 \%$ per quarter, which is consistent with the perception

\footnotetext{
${ }^{19}$ Badarinza and Ramadorai (2018) report that following elevated levels of political risk in a foreign country, the spread in housing prices in the city of London between wards that have high and low numbers of residents from the foreign country increases by $1.41 \%$ in 2 years. This estimate is lower than our MSA-level estimates, but comparable to within-MSA price differentials between high and low Chinese-populated counties, discussed below. Favilukis and Van Nieuwerburgh (2021) find that an inflow of out-of-town real estate investors (purchasing 10\% of the housing in the city center and $5 \%$ in the suburbs) causes an increase in house prices in the short run (the first period) by $6.3 \%$ and in the long run (the steady state) by $4.8 \%$.
} 
In columns 1-4 of Table 2, the sample periods of the 1997 and 2011 events are 1992:Q1-2002:Q1 and 2006:Q2-2016:Q2, but excluding the event quarters, respectively. In columns 5 and 6, the sample period is 1986:Q1-2016:Q4. We consider only those MSAs that are in the bottom or top quarter of MSAs based on state-level Chinese population in the year 1880. For columns 3, 4, and 6, the top 10\% high Chinese-populated MSAs based on 2010 Chinese population distribution (List 2 in Supplementary Material) are excluded. HCT is a dummy variable that has a value of 1 for the MSAs in the top quarter Chinesepopulated group, and 0 for the MSAs in the bottom quarter Chinese-populated group. The dependent variable is the MSAlevel quarterly real housing price growth. POST is a post-event dummy that has a value of 1 for 1997:Q2 (2011:Q3) or after for the 1997 (2011) event, and 0 otherwise. RPR is China's political risk relative to the USA based on ICRG political risk ratings of the previous calendar year. RPIGOY is the MSA-level real annual personal income growth of the current calendar year. POPGOY is the MSA-level annual population growth of the current calendar year. LAGGED_SRPIG20Q is the state-level average real personal income growth of the past 20 quarters. FUTURE_RPIG5Y is the MSA-level average real personal income growth of the next 5 calendar years or remaining calendar years for which data are available. FUTURE POPG5Y is the MSA-level average population growth of the next 5 calendar years or remaining calendar years for which data are available. MSA fixed effects are included. The robust standard errors are based on clustering at the quarter level. Estimated coefficients and the robust standard errors (in parentheses) are reported. ${ }^{* * *},{ }^{* *}$, and ${ }^{*}$ indicate the $1 \%, 5 \%$, and $10 \%$ levels of significance, respectively.

\begin{tabular}{|c|c|c|c|c|c|c|}
\hline \multirow[t]{2}{*}{ Sample } & \multicolumn{2}{|c|}{ Full } & \multicolumn{2}{|c|}{ No-Top-CN } & \multirow{2}{*}{$\begin{array}{c}\text { Full } \\
-\end{array}$} & \multirow{2}{*}{$\frac{\text { No-Top-CN }}{-}$} \\
\hline & 2011 & 1997 & 2011 & 1997 & & \\
\hline Event & 1 & 2 & 3 & 4 & 5 & 6 \\
\hline $\mathrm{POST} \times \mathrm{HCT}$ & $\begin{array}{l}0.011^{* * *} \\
(0.002)\end{array}$ & $\begin{array}{l}0.004^{\star \star \star} \\
(0.001)\end{array}$ & $\begin{array}{l}0.010^{\star \star \star} \\
(0.001)\end{array}$ & $\begin{array}{l}0.002^{\star *} \\
(0.001)\end{array}$ & & \\
\hline POST & $\begin{array}{l}0.015^{\star \star *} \\
(0.003)\end{array}$ & $\begin{array}{c}0.001 \\
(0.002)\end{array}$ & $\begin{array}{l}0.015^{\text {** }} \\
(0.003)\end{array}$ & $\begin{array}{c}0.001 \\
(0.002)\end{array}$ & & \\
\hline $\mathrm{RPR} \times \mathrm{HCT}$ & & & & & $\begin{array}{l}0.019 \text { *** } \\
(0.005)\end{array}$ & $\begin{array}{l}0.018^{\text {*ᄎ }} \\
(0.005)\end{array}$ \\
\hline RPR & & & & & $\begin{array}{c}0.011 \\
(0.009)\end{array}$ & $\begin{array}{c}0.011 \\
(0.009)\end{array}$ \\
\hline RPIGOY & $\begin{array}{l}0.102^{\star \star} \\
(0.039)\end{array}$ & $\begin{array}{l}0.080^{\star \star \star} \\
(0.020)\end{array}$ & $\begin{array}{l}0.102^{\text {*ᄎ }} \\
(0.037)\end{array}$ & $\begin{array}{l}0.063^{\star \star \star} \\
(0.018)\end{array}$ & $\begin{array}{l}0.168^{\star \star \star} \\
(0.023)\end{array}$ & $\begin{array}{l}0.157^{\star \star \star} \\
(0.022)\end{array}$ \\
\hline POPGOY & $\begin{array}{l}0.093^{\star \star \star *} \\
(0.021)\end{array}$ & $\begin{array}{l}0.373^{\star \star \star} \\
(0.035)\end{array}$ & $\begin{array}{l}0.088^{\star \star \star} \\
(0.020)\end{array}$ & $\begin{array}{l}0.334^{\star \star \star} \\
(0.035)\end{array}$ & $\begin{array}{l}0.301^{* * *} \\
(0.041)\end{array}$ & $\begin{array}{l}0.288^{\star \star \star} \\
(0.039)\end{array}$ \\
\hline LAGGED_SRPIG20Q & $\begin{array}{c}0.067 \\
(0.460)\end{array}$ & $\begin{array}{l}1.229^{\star \star \star} \\
(0.202)\end{array}$ & $\begin{array}{c}0.087 \\
(0.446)\end{array}$ & $\begin{array}{l}1.166^{\star \star \star} \\
(0.210)\end{array}$ & $\begin{array}{c}0.272 \\
(0.216)\end{array}$ & $\begin{array}{c}0.238 \\
(0.216)\end{array}$ \\
\hline FUTURE_RPIG5Y & $\begin{array}{c}0.126^{*} \\
(0.063)\end{array}$ & $\begin{array}{l}0.088^{\star \star \star} \\
(0.031)\end{array}$ & $\begin{array}{c}0.115^{\star} \\
(0.061)\end{array}$ & $\begin{array}{l}0.094^{\star \star \star} \\
(0.028)\end{array}$ & $\begin{array}{l}0.1366^{\star \star} \\
(0.054)\end{array}$ & $\begin{array}{l}0.130^{\star \star} \\
(0.053)\end{array}$ \\
\hline FUTURE_POPG5Y & $\begin{array}{l}0.578^{* * *} \\
(0.096)\end{array}$ & $\begin{array}{l}0.274^{\star \star \star} \\
(0.076)\end{array}$ & $\begin{array}{l}0.578^{\star \star *} \\
(0.095)\end{array}$ & $\begin{array}{l}0.299^{\star \star \star} \\
(0.076)\end{array}$ & $\begin{array}{c}0.080 \\
(0.066)\end{array}$ & $\begin{array}{c}0.119^{*} \\
(0.067)\end{array}$ \\
\hline $\begin{array}{l}\text { No. of obs. } \\
\text { Adj. } R^{2}\end{array}$ & $\begin{array}{l}7,025 \\
0.374\end{array}$ & $\begin{array}{l}7,520 \\
0.311\end{array}$ & $\begin{array}{l}6,790 \\
0.364\end{array}$ & $\begin{array}{l}7,120 \\
0.278\end{array}$ & $\begin{array}{r}23,524 \\
0.139\end{array}$ & $\begin{array}{r}22,168 \\
0.131\end{array}$ \\
\hline
\end{tabular}

from Figure 1 that the capital inflow after the 1997 event was more modest. The contemporaneous control variables for real personal income growth and population growth at the MSA level are all highly statistically significant, suggesting that they absorb the effects of real economic activity and demographic changes on property prices well. Past-5-year growth had a significantly positive effect on property prices around the 1997 event. The POST dummy itself is highly significant for the 2011 event, which is consistent with property prices falling in the pre-event period which includes the financial crisis. For the future growth variables, future MSA real personal income growth and population growth (to the extent that they proxy for expected future growth) have a significantly positive impact on residential prices in all regressions. All our results are also robust to the exclusion of either or both of these future growth variables.

To address the concern that results could be driven by Chinese capital inflow in certain MSAs where the Chinese population is most concentrated, for the results reported in columns 3 and 4 of Table 2 we first remove the MSAs that are in the top $10 \%$ in terms of Chinese population as of 2010 , and then identify the top and bottom 
FIGURE 3

Difference in Housing Price Growth

Figure 3 shows differences in housing price growth around 1997 and 2011 events in HCT $=1$ and HCT $=0$ U.S. MSAs (Graphs $A$ and $B$ ) and counties (Graphs $C$ and D). The events are the bursting of the Chinese property market bubble in 2011 (Graphs A and C) and Deng Xiaoping's death in 1997 (Graphs B and D). The dashed lines show the 95\% confidence intervals (Cl) of the difference (solid line).
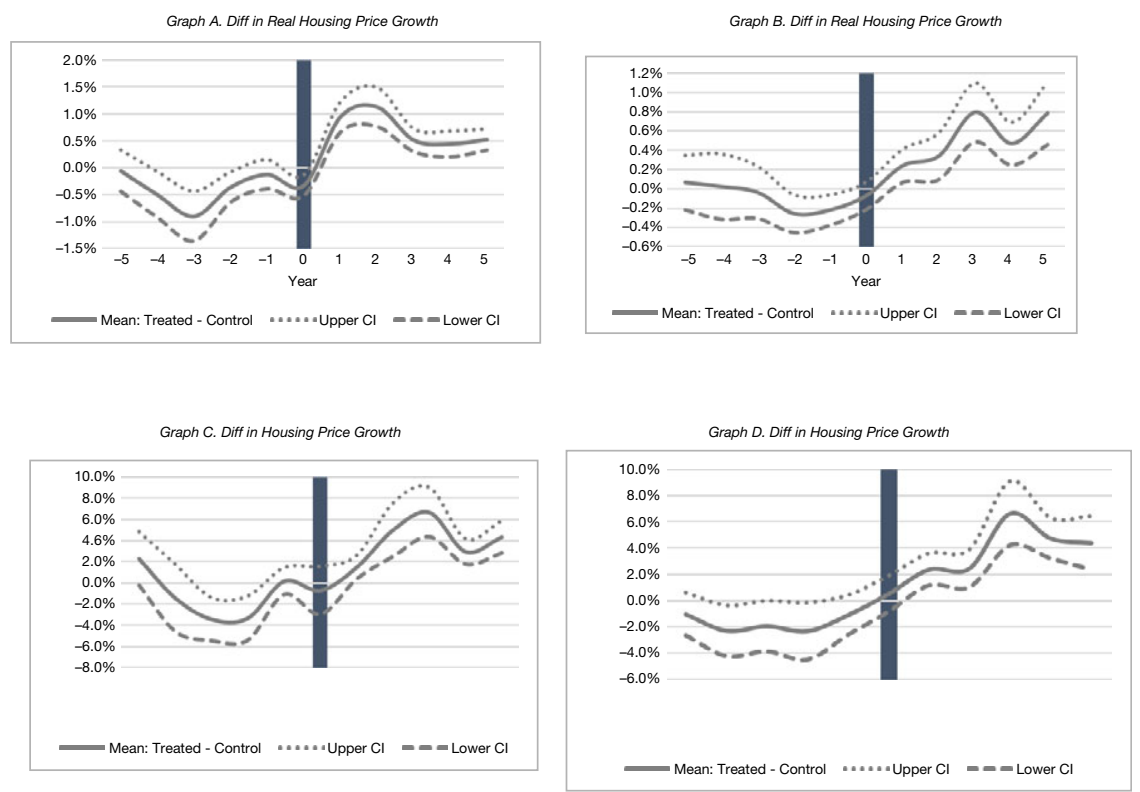

quartiles of the remaining MSAs based on their 1880 state-level Chinese population. In Table OA1 of the Supplementary Material, List 2 gives a list of the MSAs that are removed, and the last column of List 3 indicates which states remain in the sample. The results, reported in columns 3 and 4 of Table 2, are qualitatively similar, although the economic magnitude for the 1997 event is smaller than that for the full sample. ${ }^{20}$

Graphs A and B in Figure 3 show that the parallel trends assumption holds for our difference-in-differences methodology. The solid line denotes the difference in the annual average of the quarterly housing price growth between the HCT $=1$ and HCT $=0$ MSAs, and the dashed lines show the 95 percentile confidence intervals. The difference is not significant at the $5 \%$ level in the pre-event period, and only becomes significantly positive in the post-event period, for both events.

One caveat with the analysis in Table 2 is that, especially during the 1997 event period which coincided with the Asian financial crisis, capital inflow to the USA also took place from several Asian countries such as Thailand and South Korea, and is also likely to have followed ethnic links with the corresponding

\footnotetext{
${ }^{20}$ In Section VIII.B, we show that when regions are classified based on early overall U.S. population distribution (as opposed to the distribution of Chinese population), we do not find similar results around the two events. This mitigates the concern that classifications based on early population distributions are associated with regional characteristics that persist over long periods and potentially bias our results.
} 
TABLE 3

Chinese Capital Inflow and Real Housing Price Growth in U.S. MSAs, Controlling for Non-Chinese Asian Population

\begin{tabular}{|c|c|c|}
\hline & 2011 & 1997 \\
\hline Event & 1 & 2 \\
\hline $\mathrm{POST} \times \mathrm{HCT}$ & $\begin{array}{l}0.011^{\star \star \star} \\
(0.002)\end{array}$ & $\begin{array}{l}0.003^{\text {*ᄎ }} \\
(0.001)\end{array}$ \\
\hline POST & $\begin{array}{l}0.015^{\star \star \star} \\
(0.004)\end{array}$ & $\begin{array}{c}0.001 \\
(0.002)\end{array}$ \\
\hline POST $\times$ NON-CHINESE_ASIAN_POPULATION & $\begin{array}{c}0.004 \\
(0.003)\end{array}$ & $\begin{array}{l}0.031^{\star \star \star} \\
(0.003)\end{array}$ \\
\hline RPIGOY & $\begin{array}{l}0.104^{\star \star} \\
(0.040)\end{array}$ & $\begin{array}{l}0.079^{\text {*** }} \\
(0.019)\end{array}$ \\
\hline POPGOY & $\begin{array}{l}0.088^{\star \star \star} \\
(0.020)\end{array}$ & $\begin{array}{l}0.348^{\text {** }} \\
(0.036)\end{array}$ \\
\hline LAGGED_SRPIG20Q & $\begin{array}{c}0.013 \\
(0.477)\end{array}$ & $\begin{array}{l}1.173^{\star \star \star} \\
(0.220)\end{array}$ \\
\hline FUTURE_RPIG5Y & $\begin{array}{c}0.114 \\
(0.077)\end{array}$ & $\begin{array}{l}0.097^{\star \star \star} \\
(0.029)\end{array}$ \\
\hline FUTURE_POPG5Y & $\begin{array}{l}0.577^{\star \star \star} \\
(0.092)\end{array}$ & $\begin{array}{l}0.304^{\star \star \star} \\
(0.071)\end{array}$ \\
\hline $\begin{array}{l}\text { No. of obs. } \\
\text { Adj. } R^{2}\end{array}$ & $\begin{array}{l}6,505 \\
0.382\end{array}$ & $\begin{array}{l}7,000 \\
0.342 \\
\end{array}$ \\
\hline
\end{tabular}

U.S.-based population. Since there was some degree of overlap between these population groups and the Chinese, we control for non-Chinese Asian population number, based on 2010 population, at the MSA level. The results are reported in Table 3. We find that MSAs with high Chinese population still experience faster property price growth after both events. For the 1997 event, regions with higher non-Chinese Asian population also experience higher property price growth after the event. However, these regions actually experience significantly lower property price growth after the 2011 event, which could reflect a decrease in capital inflow from other Asian countries after the financial crisis.

Finally, in columns 5 and 6 of Table 2, we report results for reduced form regressions involving RPR. An increase in RPR in general has a marginally significant positive effect on the following year's residential prices in MSAs without strong ties according to our classifications, ${ }^{21}$ but this effect is magnified in $\mathrm{HCT}=1$ MSAs.

\footnotetext{
${ }^{21}$ This could reflect the strongly positive significant effect of POST in Table 2 for the 2011 event, during which RPR also reached higher values due to higher political risk in China.
} 


\section{B. Annual Employment Growth and Deposit Growth}

Capital inflows are likely to have significant employment effects for the regional economies. This can happen not only via the creation of more jobs in the real estate sector, but also indirectly, via deposit creation at local banks and increased bank lending. Industry reports have suggested that many Chinese banks have become a major source of debt capital in the USA and Chinese developers became very active in commercial real estate development after the year 2011. Favilukis and Van Nieuwerburgh (2021) develop a calibrated general equilibrium model to estimate the effect of out-of-town (OOT) home buyers who buy but do not rent out housing units in metropolitan cities. Their model implies economically significant effects of OOT capital inflows to the residential markets on rentals and sectoral employment, which spill over to suburbs.

Not surprisingly, the construction sector is one of the major beneficiaries of such OOT inflow to the residential sector. The model, however, assumes that the labor market clears, so there are no aggregate employment effects. We follow an empirical approach similar to that for our analysis of CINFC on residential prices, and document significant employment effects not only in the construction sector, but also for all other sectors combined. The results for the two events appear in Table 4. Columns 1 and 2 present results for overall MSA-level employment, columns 3 and 4 present results for the construction sector, and columns 5 and 6 present results for all nonconstruction sectors combined. The results show that POST $\times$ HCT has a significant positive effect on employment growth for the 2011

\section{TABLE 4}

Chinese Capital Inflow and Employment and Deposit Growth in U.S. MSAs (1997 and 2011 Events)

In Table 4, the sample periods of the 1997 and 2011 events are 1992:Q1-2002:Q1 and 2006:Q2-2016:Q2, but exclude the event years, respectively. We consider only those MSAs that are in the bottom or top quarter of the 1880 state-level Chinese population of all MSAs. In columns 1 and 2, the dependent variable is the MSA-level annual overall employment growth. In columns 3 and 4 , the dependent variable is the MSA-level annual employment growth of the construction sector. In columns 5 and 6 , the dependent variable is the MSA-level annual employment growth of the nonconstruction sector. In column 7, the dependent variable is the MSA-level quarterly deposit growth. HCT is a dummy variable that has a value of 1 for the MSAs in the top quarter Chinese-populated group, and 0 for the MSAs in the bottom quarter Chinese-populated group. POST is a postevent dummy that has a value of 1 for 1998 (2012) or after for the 1997 (2011) event, and 0 otherwise. LAGGED_SRPIG20Q is the state-level average real personal income growth of the past 20 quarters. MSA fixed effects are included. The robust standard errors are based on clustering at the year or quarter level. Estimated coefficients and the robust standard errors (in parentheses) are reported. ${ }^{\star \star \star}{ }^{* *}{ }^{\star *}{ }^{*}$, and \# indicate the $1 \%, 5 \%, 10 \%$, and 1 -sided $10 \%$ levels of significance, respectively. \# indicates a p-value of 0.155

Dependent Variable

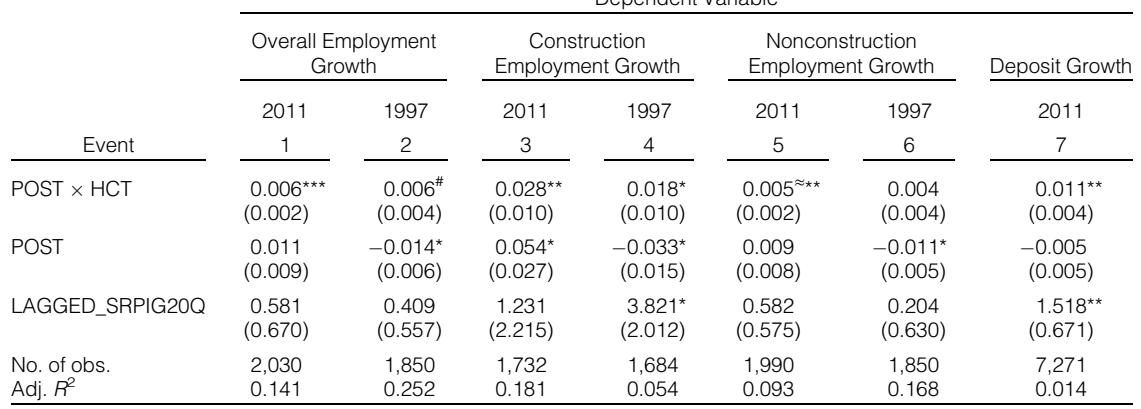


event. For the 1997 event, while the coefficient is positive, it is significant at conventional levels only for the construction sector. ${ }^{22}$

The quantitative effect on the construction sector is 3 to 5 times as large as for overall employment, for both the 1997 and the 2011 events. The difference-indifferences coefficient HCT $\times$ POST capturing the effect of CINFC on the growth rate of construction sector employment is larger following the 2011 event $(2.8 \%$ higher in HCT $=1$ MSAs than HCT $=0$ MSAs) than for the 1997 event $(1.8 \%$ higher). The effect is also stronger after the second event for employment growth in all nonconstruction sectors combined. The economically larger impact of CINFC on employment growth following the 2011 event compared to the 1997 event is consistent with the observation that the labor market was weaker in 2010 than in 1996 (the unemployment rate was $10 \%$ and 6\%, respectively, for these years).

As for the effect on deposit creation, information on MSA-level deposits is available only from the year 2002. Hence, in the last column of Table 4, we report results for the 2011 event, for which quarterly deposit growth is the dependent variable. The coefficient of HCT $\times$ POST is highly significant, and the magnitude of the coefficient suggests that deposit growth in the MSAs with strong Chinese ties is more than $4 \%$ higher than that in MSAs with weak Chinese ties.

Reduced-form regressions are reported for both employment growth and bank deposit growth in Table 5. In the first 2 columns in Table 5, overall employment growth is the dependent variable, while in the third and fourth columns, it is the

TABLE 5

Transmission Channel: Chinese Capital Inflows, Relative Political Risk, and Employment and Deposit Growth

The sample period in Table 5 is 2002-2016. We consider only those MSAs that are in the bottom or top quarter of the 1880 state-level Chinese population of all MSAs. In columns 1 and 2, the dependent variable is the MSA-level annual overall employment growth. In columns 3 and 4, the dependent variable is the MSA-level annual employment growth of the construction sector. In columns 5 and 6 , the dependent variable is the average of the MSA-level quarterly deposit growth in a year. HCT is a dummy variable that has a value of 1 for the MSAs in the top quarter Chinese-populated group, and 0 for the MSAs in the bottom quarter Chinese-populated group. RPR is China's political risk relative to the USA based on ICRG political risk ratings of the previous calendar year. The dependent variable is the MSA-level quarterly deposit growth. LAGGED_REAL_ HOUSING_PRICE_GROWTH is the average of the MSA-level quarterly real housing price growth, as a percentage, of the previous calendar year. LAGGED SRPIG20Q is the state-level average real personal income growth, as a percentage, of the past 20 quarters. MSA fixed effects are included. The robust standard errors are based on clustering at the year level. Estimated coefficients and the robust standard errors (in parentheses) are reported. ***, **, and * indicate the $1 \%, 5 \%$, and $10 \%$ levels of significance, respectively.

Dependent Variable

\begin{tabular}{|c|c|c|c|c|c|c|}
\hline & \\
\hline & \multicolumn{2}{|c|}{ Overall Employment Growth } & \multicolumn{2}{|c|}{$\begin{array}{l}\text { Construction } \\
\text { Employment Growth }\end{array}$} & \multicolumn{2}{|c|}{ Deposit Growth } \\
\hline & 1 & 2 & 3 & 4 & 5 & 6 \\
\hline $\mathrm{RPR} \times \mathrm{HCT}$ & $\begin{array}{l}0.025^{\star * \star} \\
(0.008)\end{array}$ & $\begin{array}{c}0.010 \\
(0.011)\end{array}$ & $\begin{array}{l}0.076^{\star} \\
(0.041)\end{array}$ & $\begin{array}{r}0.036^{\star} \\
(0.021)\end{array}$ & $\begin{array}{r}0.033^{*} \\
(0.019)\end{array}$ & $\begin{array}{l}0.029^{\star *} \\
(0.013)\end{array}$ \\
\hline RPR & $\begin{array}{c}-0.004 \\
(0.029)\end{array}$ & $\begin{array}{c}-0.003 \\
(0.018)\end{array}$ & $\begin{array}{c}0.066 \\
(0.095)\end{array}$ & $\begin{array}{c}0.038 \\
(0.061)\end{array}$ & $\begin{array}{r}-0.032^{\star} \\
(0.018)\end{array}$ & $\begin{array}{r}-0.037^{\star} \\
(0.020)\end{array}$ \\
\hline $\begin{array}{l}\text { LAGGED_REAL_HOUSING_ } \\
\text { PRICE_GROWTH }\end{array}$ & & $\begin{array}{l}0.006^{\star \star \star} \\
(0.001)\end{array}$ & & $\begin{array}{l}0.027^{\star \star \star} \\
(0.004)\end{array}$ & & $\begin{array}{l}0.003^{*} \\
(0.001)\end{array}$ \\
\hline LAGGED_SRPIG20Q & $\begin{array}{c}-0.002 \\
(0.006)\end{array}$ & $\begin{array}{c}-0.010 \\
(0.006)\end{array}$ & $\begin{array}{c}0.011 \\
(0.027)\end{array}$ & $\begin{array}{l}-0.025 \\
(0.022)\end{array}$ & $\begin{array}{l}0.021^{\star \star} \\
(0.008)\end{array}$ & $\begin{array}{c}0.015 \\
(0.009)\end{array}$ \\
\hline $\begin{array}{l}\text { No. of obs. } \\
\text { Adj. } R^{2}\end{array}$ & $\begin{array}{l}3,184 \\
0.088\end{array}$ & $\begin{array}{l}2,655 \\
0.360\end{array}$ & $\begin{array}{l}2,747 \\
0.001\end{array}$ & $\begin{array}{l}2,452 \\
0.406\end{array}$ & $\begin{array}{l}2,748 \\
0.059\end{array}$ & $\begin{array}{l}2,613 \\
0.073\end{array}$ \\
\hline
\end{tabular}

\footnotetext{
${ }^{22}$ The results (not reported) are similar when we exclude the top $10 \%$ Chinese MSAs.
} 
growth rate of construction sector employment. Finally, in the last 2 columns, we consider deposit growth (the annual average of all quarters). In even columns, we also include lagged residential price growth (annual average of all quarters) to examine whether the impact on the real economy is a direct outcome of the capital flow, or an indirect implication of developments in the housing market. Our hypothesis is that any impact that works through the housing price channel will be reflected in a positive significant effect of lagged housing price growth on the variable of interest; however, if housing prices do not directly affect the variable, but the inflow does, then the interaction of lagged RPR and HCT will be significant. To ensure a meaningful comparison, the sample period is 2002-2016 (for which deposit information is available) in each regression.

In columns 1 and 3 of Table 5, we find that the coefficient of HCT $\times$ RPR is positive for overall employment growth as well as for the construction sector. While it is marginally insignificant for the construction sector, the magnitude is three times that for overall employment. However, both coefficients become insignificant when lagged housing price growth is included in the regression, as seen in columns 2 and 4. Lagged housing price growth itself is significant at the $1 \%$ level. These findings suggest that the housing sector plays a significant role in the process of employment creation and the effect of CINFC on employment works mainly through this sector. In contrast, in columns 5 and 6, for deposit growth, the coefficient of RPR $\times$ HCT remains positive and significant irrespective of whether lagged housing price growth is included. Lagged housing price growth itself is significant at the $10 \%$ level in column 6 , but its inclusion has little effect on the coefficient of RPR $\times$ HCT. These results are consistent with deposit growth mainly responding to capital inflows.

\section{County-Level Housing Price Growth and Spillovers}

\section{A. County-Level Annual Housing Price Growth and Employment Growth}

Our data on county-level housing price growth is available to us only in nominal terms and at an annual frequency. We first conduct analysis at the county-level, similar to the MSA-level analysis in the previous section. Here, HCT $=1$ if a county has above-median Chinese population as of 1870 , and HCT $=0$ if the country has no recorded Chinese population in that year. ${ }^{23}$ The results are reported in Table 6. The regressions include county fixed effects, contemporaneous and past5 -year (nominal) personal income growth, and population growth. The coefficient of HCT $\times$ POST is positive and significant for both the 1997 and 2011 events, and the implied magnitudes are very close to those from the MSA-level analysis.

Graphs $\mathrm{C}$ and D in Figure 3 show that the housing price changes in $\mathrm{HCT}=1$ and $\mathrm{HCT}=0$ counties do not differ significantly prior to each event; however, the difference becomes significant after each event, validating our difference-indifferences methodology.

\footnotetext{
${ }^{23}$ Such a classification is convenient given that in 1870 there were many counties without any recorded Chinese population. Our results are similar for alternative definitions of HCT, such as the top 25 th and bottom 25 th percentile among counties with recorded Chinese population.
} 
In columns 1-4 of Table 6, the sample periods of the 1997 and 2011 events are 1992-2002 and 2006-2016, but exclude the event years, respectively. In columns 5 and 6, the sample period is 1986-2016. For "No-Top-CN" samples, the top 10\% Chinese-populated MSAs (List 2 in the Supplementary Material) are excluded. The dependent variable is the county-level annual nominal housing price growth. HCT is a dummy variable that has a value of $1(0)$ if the 1870 county-level Chinese population, by number, is above the median (not reported). POST is a post-event dummy that has a value of 1 if it is in 1998 (2012) or after for the 1997 (2011) event, and 0 otherwise. RPR is China's political risk relative to the USA based on ICRG political risk ratings of the previous calendar year. PIGOY is the contemporaneous county-level annual nominal personal income growth. POPGOY is the contemporaneous county-level annual population growth. FUTURE_PIG5Y is the average county-level nominal personal income growth of the next 5 years or remaining years for which data are available. FUTURE_POPG5Y is the average county-level population growth of the next 5 years or remaining years for which data are available. County fixed effects are included. The robust standard errors are based on clustering at the year level. Estimated coefficients and the robust standard errors (in parentheses) are reported. ${ }^{* * *}$, ${ }^{* *}$, and ${ }^{*}$ indicate the $1 \%, 5 \%$, and $10 \%$ levels of significance, respectively. \# indicates a $p$-value of 0.117 .

\begin{tabular}{|c|c|c|c|c|c|c|}
\hline \multirow[t]{2}{*}{ Sample } & \multicolumn{2}{|c|}{ Full } & \multicolumn{2}{|c|}{ No-Top-CN } & \multirow{2}{*}{$\begin{array}{c}\text { Full } \\
-\end{array}$} & \multirow{2}{*}{$\frac{\text { No-Top-CN }}{-}$} \\
\hline & 2011 & 1997 & 2011 & 1997 & & \\
\hline Event & 1 & 2 & 3 & 4 & 5 & 6 \\
\hline POST $\times$ HCT & $\begin{array}{c}0.055^{\star \star} \\
(0.021)\end{array}$ & $\begin{array}{l}0.040^{\star \star \star} \\
(0.008)\end{array}$ & $\begin{array}{l}0.053^{* *} \\
(0.021)\end{array}$ & $\begin{array}{l}0.036^{\star \star \star} \\
(0.009)\end{array}$ & & \\
\hline POST & $\begin{array}{c}0.018 \\
(0.016)\end{array}$ & $\begin{array}{c}0.003 \\
(0.005)\end{array}$ & $\begin{array}{c}0.016 \\
(0.016)\end{array}$ & $\begin{array}{c}0.001 \\
(0.005)\end{array}$ & & \\
\hline $\mathrm{RPR} \times \mathrm{HCT}$ & & & & & $\begin{array}{c}0.102^{*} \\
(0.055)\end{array}$ & $\begin{array}{c}0.090^{\#} \\
(0.056)\end{array}$ \\
\hline RPR & & & & & $\begin{array}{c}0.016 \\
(0.037)\end{array}$ & $\begin{array}{c}0.010 \\
(0.036)\end{array}$ \\
\hline PIGOY & $\begin{array}{l}0.229^{* *} \\
(0.084)\end{array}$ & $\begin{array}{l}0.084^{\star \star} \\
(0.034)\end{array}$ & $\begin{array}{l}0.208^{* *} \\
(0.080)\end{array}$ & $\begin{array}{c}0.074^{\star} \\
(0.033)\end{array}$ & $\begin{array}{l}0.190^{\star *} \\
(0.076)\end{array}$ & $\begin{array}{l}0.172^{\star \star} \\
(0.072)\end{array}$ \\
\hline POPGOY & $\begin{array}{l}0.521^{* \star *} \\
(0.141)\end{array}$ & $\begin{array}{l}0.589^{\star \star \star} \\
(0.100)\end{array}$ & $\begin{array}{l}0.514^{* * *} \\
(0.131)\end{array}$ & $\begin{array}{l}0.551^{\star \star \star} \\
(0.099)\end{array}$ & $\begin{array}{l}0.677^{\star \star \star} \\
(0.174)\end{array}$ & $\begin{array}{l}0.669^{\star \star \star} \\
(0.171)\end{array}$ \\
\hline FUTURE_PIG5Y & $\begin{array}{c}0.191^{*} \\
(0.102)\end{array}$ & $\begin{array}{c}-0.118 \\
(0.068)\end{array}$ & $\begin{array}{c}0.157 \\
(0.092)\end{array}$ & $\begin{array}{c}-0.099 \\
(0.069)\end{array}$ & $\begin{array}{c}0.127 \\
(0.117)\end{array}$ & $\begin{array}{c}0.131 \\
(0.109)\end{array}$ \\
\hline FUTURE_POPG5Y & $\begin{array}{l}1.952^{\star \star \star} \\
(0.593)\end{array}$ & $\begin{array}{c}0.257^{\star \star} \\
(0.102)\end{array}$ & $\begin{array}{l}2.009^{* * *} \\
(0.577)\end{array}$ & $\begin{array}{c}0.287^{\text {** }} \\
(0.104)\end{array}$ & $\begin{array}{l}0.808^{\star \star \star} \\
(0.275)\end{array}$ & $\begin{array}{l}0.904^{\star \star \star} \\
(0.271)\end{array}$ \\
\hline $\begin{array}{l}\text { No. of obs. } \\
R^{2}\end{array}$ & $\begin{array}{r}25,610 \\
0.202\end{array}$ & $\begin{array}{r}19,913 \\
0.180\end{array}$ & $\begin{array}{r}24,450 \\
0.192\end{array}$ & $\begin{array}{r}18,754 \\
0.175\end{array}$ & $\begin{array}{r}65,831 \\
0.135\end{array}$ & $\begin{array}{r}62,193 \\
0.132\end{array}$ \\
\hline
\end{tabular}

We also replicate the MSA-level employment analysis reported in Table 4 at the county level, using county and year fixed effects. Results (not reported) are qualitatively the same.

\section{B. Within-MSA Housing Price Growth and Spillovers}

Within-MSA comparisons are likely less susceptible (than comparisons between MSAs located in different states) to the issue that other factors such as local economic activity may be correlated with Chinese population presence, since economic shocks can spill over more easily to adjoining counties than across states. The within-MSA regressions include MSA interacted with year fixed effects, which implies that the coefficient estimate of HCT captures within-MSA differences between high and low Chinese-populated counties.

Results in the first 4 columns in Table 7 show that after both events, the housing price growth is higher for HCT $=1$ counties than for $\mathrm{HCT}=0$ counties within the same MSA. For the 2011 event, the difference is about $0.5 \%$ per year in nominal terms, but marginally insignificant at conventional levels. It is about $1.1 \%$ per year for the 1997 event. 
TABLE 7

Chinese Capital Inflow and Nominal Housing Price Growth in U.S. Counties, Within MSA-Year Comparison

\begin{tabular}{|c|c|c|c|c|c|c|}
\hline \multirow[t]{2}{*}{ Sample } & \multicolumn{2}{|c|}{ Full } & \multicolumn{2}{|c|}{ No-Top-CN } & \multirow{2}{*}{$\frac{\text { Full }}{-}$} & \multirow{2}{*}{$\frac{\text { No-Top-CN }}{-}$} \\
\hline & 2011 & 1997 & 2011 & 1997 & & \\
\hline Event & 1 & 2 & 3 & 4 & 5 & 6 \\
\hline POST $\times$ HCT & $\begin{array}{c}0.005 \\
(0.005)\end{array}$ & $\begin{array}{l}0.013^{\star * *} \\
(0.005)\end{array}$ & $\begin{array}{l}0.012^{\star \star} \\
(0.005)\end{array}$ & $\begin{array}{l}0.011^{* *} \\
(0.005)\end{array}$ & & \\
\hline $\mathrm{RPR} \times \mathrm{HCT}$ & & & & & $\begin{array}{l}0.021^{\star * *} \\
(0.008)\end{array}$ & $\begin{array}{l}0.020^{* * *} \\
(0.006)\end{array}$ \\
\hline НCT & $\begin{array}{c}0.012^{*} \\
(0.007)\end{array}$ & $\begin{array}{r}-0.004^{*} \\
(0.002)\end{array}$ & $\begin{array}{c}0.003 \\
(0.003)\end{array}$ & $\begin{array}{c}-0.005^{* * *} \\
(0.002)\end{array}$ & $\begin{array}{c}-0.021^{* *} \\
(0.009)\end{array}$ & $\begin{array}{c}-0.023^{* *} \\
(0.009)\end{array}$ \\
\hline PIGOY & $\begin{array}{l}0.045^{\star \star} \\
(0.020)\end{array}$ & $\begin{array}{c}0.031 \\
(0.020)\end{array}$ & $\begin{array}{c}0.035^{*} \\
(0.020)\end{array}$ & $\begin{array}{c}0.025 \\
(0.020)\end{array}$ & $\begin{array}{l}0.041^{\text {***}} \\
(0.013)\end{array}$ & $\begin{array}{l}0.034^{* *} \\
(0.013)\end{array}$ \\
\hline POPGOY & $\begin{array}{l}0.125^{\star \star \star} \\
(0.012)\end{array}$ & $\begin{array}{c}0.072 \\
(0.085)\end{array}$ & $\begin{array}{l}0.125^{\star \star \star} \\
(0.008)\end{array}$ & $\begin{array}{c}0.034 \\
(0.068)\end{array}$ & $\begin{array}{l}0.108^{\star \star *} \\
(0.013)\end{array}$ & $\begin{array}{l}0.107^{\star * *} \\
(0.012)\end{array}$ \\
\hline FUTURE_PIG5Y & $\begin{array}{c}0.072 \\
(0.054)\end{array}$ & $\begin{array}{l}0.069^{\star * *} \\
(0.023)\end{array}$ & $\begin{array}{c}0.030 \\
(0.038)\end{array}$ & $\begin{array}{l}0.078^{* *} \\
(0.031)\end{array}$ & $\begin{array}{c}0.059^{\star *} \\
(0.028)\end{array}$ & $\begin{array}{c}0.046^{*} \\
(0.026)\end{array}$ \\
\hline FUTURE_POPG5Y & $\begin{array}{c}-0.101 \\
(0.061)\end{array}$ & $\begin{array}{r}-0.186^{\star} \\
(0.100)\end{array}$ & $\begin{array}{c}-0.083 \\
(0.059)\end{array}$ & $\begin{array}{r}-0.137^{*} \\
(0.079)\end{array}$ & $\begin{array}{c}-0.191^{\star \star *} \\
(0.056)\end{array}$ & $\begin{array}{l}-0.152^{\star \star \star} \\
(0.056)\end{array}$ \\
\hline $\begin{array}{l}\text { No. of obs. } \\
R^{2}\end{array}$ & $\begin{array}{l}8,214 \\
0.933\end{array}$ & $\begin{array}{l}8,050 \\
0.834\end{array}$ & $\begin{array}{l}6,887 \\
0.935\end{array}$ & $\begin{array}{l}6,731 \\
0.817\end{array}$ & $\begin{array}{r}25,332 \\
0.917\end{array}$ & $\begin{array}{r}21,175 \\
0.912\end{array}$ \\
\hline
\end{tabular}

In the last 2 columns of Table 7, we present results from reduced-form regressions using RPR. The effect of RPR is significantly higher for HCT $=1$ counties than for HCT $=0$ counties. These results also indicate that even within the same MSA, capital flight from China driven by higher RPR has a larger effect on residential property prices in counties that have stronger ethnic links to China.

An interesting aspect of the results is that the effects are quantitatively weaker for the 2011 event when all the MSAs with Chinese population are kept in the sample (first column in Table 7), compared to the corresponding regression for the 1997 event (column 3) or when counties from the top 10\% Chinese MSAs are excluded from the sample (column 2). In fact, compared to the MSA-level results in Table 2 or the county-level results in Table 6, the within-MSA results for counties in Table 7 are quantitatively weaker. We hypothesize that this has to do with the fact that counties in the same MSA experience more similar property price growth than MSAs in different states, irrespective of population distribution. An important reason for this is that spillover effects are likely to be more important across counties within the same MSA than across MSAs. Since the post-2011 outflows were more significant, the property price increases in the high Chinese-populated counties were more substantial, which spilled over to the low Chinese-populated counties. This reduced the between-county differences within the same MSA. 
TABLE 8

Spillover Effects of Chinese Capital Inflows: Housing Price Growth in U.S. Counties Without Chinese Population (1997 and 2011 Events)

In Table 8, the sample periods for the 1997 and 2011 events are 1992-2002 and 2006-2016, respectively. The event years are excluded. We consider only counties that have no recorded Chinese population as of 2010. The dependent variable is the county-level annual nominal housing price growth. HCT is a dummy variable that has a value of 1 if the 2010 state-level Chinese population (by number or proportion) is above the median of the sample and 0 otherwise. For "No top-CN" samples, states with a top $10 \%$ Chinese-populated MSA (List 3 in Supplementary Material) are excluded. POST is a post-event dummy that has a value of 1 if it is in 1998 (2012) or after for the 1997 (2011) event, and 0 otherwise. PIGOY is the contemporaneous county-level annual nominal personal income growth. POPGOY is the contemporaneous county-level annual population growth. FUTURE_PIG5Y is the average county-level nominal personal income growth of the next 5 years or the remaining years for which data are available. FUTURE_POPG5Y is the average county-level population growth of the next 5 years or the remaining years for which data are available. County and year fixed effects are included. The robust standard errors are based on clustering at the state level. Estimated coefficients and the robust standard errors (in parentheses) are reported. ${ }^{\star \star \star}$, ${ }^{\star \star}$, and ${ }^{*}$ indicate the $1 \%, 5 \%$, and $10 \%$ levels of significance, respectively.

\begin{tabular}{|c|c|c|c|c|c|c|c|c|}
\hline Sample & \multicolumn{4}{|c|}{ Full } & \multicolumn{4}{|c|}{ No Top-CN } \\
\hline Event & \multicolumn{2}{|c|}{2011} & \multicolumn{2}{|c|}{1997} & \multicolumn{2}{|c|}{2011} & \multicolumn{2}{|c|}{1997} \\
\hline & Proportion & Number & Proportion & Number & Proportion & Number & Proportion & Number \\
\hline HIGH CHINESE & 1 & 2 & 3 & 4 & 5 & 6 & 7 & 8 \\
\hline POST $\times$ HCT & $\begin{array}{l}0.016^{\star \star \star} \\
(0.005)\end{array}$ & $\begin{array}{l}0.014 \approx \approx \star \star \star \\
(0.005)\end{array}$ & $\begin{array}{l}0.011^{\star \star} \\
(0.005)\end{array}$ & $\begin{array}{l}0.014^{* * *} \\
(0.005)\end{array}$ & $\begin{array}{l}0.016^{\star *} \\
(0.006)\end{array}$ & $\begin{array}{l}0.013^{\star \star} \\
(0.006)\end{array}$ & $\begin{array}{r}1.7 e-4 \\
(0.006)\end{array}$ & $\begin{array}{r}4.9 e-4 \\
(0.006)\end{array}$ \\
\hline НCT & $\begin{array}{l}-0.012^{\star \star \star} \\
(0.004)\end{array}$ & $\begin{array}{c}-0.012^{\star \star \star} \\
(0.004)\end{array}$ & $\begin{array}{r}-0.007^{*} \\
(0.004)\end{array}$ & $\begin{array}{c}-0.009^{\star \star} \\
(0.004)\end{array}$ & $\begin{array}{c}-0.013^{\star * *} \\
(0.004)\end{array}$ & $\begin{array}{c}-0.013^{\star \star \star} \\
(0.004)\end{array}$ & $\begin{array}{c}0.003 \\
(0.004)\end{array}$ & $\begin{array}{c}0.001 \\
(0.004)\end{array}$ \\
\hline PIGOY & $\begin{array}{l}0.099^{\star \star \star} \\
(0.021)\end{array}$ & $\begin{array}{l}0.095^{\star * *} \\
(0.021)\end{array}$ & $\begin{array}{l}0.073^{\star \star *} \\
(0.017)\end{array}$ & $\begin{array}{l}0.075^{\star \star \star} \\
(0.017)\end{array}$ & $\begin{array}{l}0.071^{\text {***}} \\
(0.022)\end{array}$ & $\begin{array}{l}0.069^{\star \star \star} \\
(0.023)\end{array}$ & $\begin{array}{l}0.044^{\star \star} \\
(0.017)\end{array}$ & $\begin{array}{l}0.044^{\star \star} \\
(0.017)\end{array}$ \\
\hline POPGOY & $\begin{array}{l}0.239^{\star \star \star} \\
(0.088)\end{array}$ & $\begin{array}{l}0.242^{\star \star \star} \\
(0.089)\end{array}$ & $\begin{array}{l}0.379^{\star \star \star} \\
(0.058)\end{array}$ & $\begin{array}{l}0.373^{\star \star *} \\
(0.058)\end{array}$ & $\begin{array}{l}0.222^{* *} \\
(0.085)\end{array}$ & $\begin{array}{l}0.224^{\star \star} \\
(0.088)\end{array}$ & $\begin{array}{l}0.400^{\star \star \star} \\
(0.066)\end{array}$ & $\begin{array}{l}0.400^{\star \star \star} \\
(0.066)\end{array}$ \\
\hline FUTURE_PIG5Y & $\begin{array}{c}-0.038 \\
(0.049)\end{array}$ & $\begin{array}{c}-0.048 \\
(0.051)\end{array}$ & $\begin{array}{c}-0.033 \\
(0.036)\end{array}$ & $\begin{array}{c}-0.021 \\
(0.034)\end{array}$ & $\begin{array}{r}-0.095^{*} \\
(0.049)\end{array}$ & $\begin{array}{c}-0.118^{\star \star \star} \\
(0.041)\end{array}$ & $\begin{array}{c}-0.062 \\
(0.040)\end{array}$ & $\begin{array}{c}-0.063 \\
(0.045)\end{array}$ \\
\hline FUTURE_POPG5Y & $\begin{array}{l}0.540^{\star \star *} \\
(0.094)\end{array}$ & $\begin{array}{l}0.556^{* \star *} \\
(0.095)\end{array}$ & $\begin{array}{c}-0.006 \\
(0.060)\end{array}$ & $\begin{array}{c}-0.019 \\
(0.058)\end{array}$ & $\begin{array}{l}0.665^{\text {***}} \\
(0.119)\end{array}$ & $\begin{array}{l}0.706^{\star \star \star} \\
(0.117)\end{array}$ & $\begin{array}{c}0.061 \\
(0.069)\end{array}$ & $\begin{array}{c}0.060 \\
(0.069)\end{array}$ \\
\hline $\begin{array}{l}\text { No. of obs. } \\
R^{2}\end{array}$ & $\begin{array}{r}23,538 \\
0.380\end{array}$ & $\begin{array}{r}23,538 \\
0.378\end{array}$ & $\begin{array}{r}17,761 \\
0.172\end{array}$ & $\begin{array}{r}17,761 \\
0.175\end{array}$ & $\begin{array}{r}14,998 \\
0.360\end{array}$ & $\begin{array}{r}14,998 \\
0.358\end{array}$ & $\begin{array}{r}11,020 \\
0.215\end{array}$ & $\begin{array}{r}11,020 \\
0.214\end{array}$ \\
\hline
\end{tabular}

To investigate the presence of spillover effects, in Table 8 we consider counties with no reported Chinese population as of 2010. We examine whether property price appreciation in these counties was higher in the post-event periods when their states had a greater Chinese population (as of 2010), With more recent population data, we can report results based on both the number of Chinese and the proportion of Chinese in the state population. Consistent with spillover effects, we find that when all states are considered for both events, the property price growth in the post-period increased for non-Chinese counties in high Chinese population states by about $1.5 \%$ per year more than in non-Chinese counties in low Chinese population states. However, as shown in the last 2 columns in Table 8, there was no such effect after the 1997 event when states with at least one major (top 10\%) Chinese-populated MSA are excluded. The absence of spillover for the states without a significant Chinese-populated MSA after the 1997 event is consistent with the fact that capital inflows from China to the USA in the earlier period were geographically more concentrated in states with significant Chinese presence.

Spillover effects are expected to decay as a non-Chinese-populated county is farther away from the main destination(s) of CINFC. To test this hypothesis, we first identify the top $20 \%$ of Chinese-populated counties in the USA, based on 2010 population. Next, we calculate the average distance, in kilometers, of a non-Chinese 
TABLE 9

Spillovers and Distance-Decay: Housing Price Growth in Non-Chinese Counties (1997 and 2011 Events)

In Table 9, the sample periods of the 1997 and 2011 events are 1992-2002 and 2006-2016, but exclude the event years. We consider only counties that have no recorded Chinese population as of 2010 . We first identify the top $20 \%$ Chinese-populated counties in the USA, based on the Census 2010 population. Next, we calculate the distance (average distance) of a nonChinese county (in any state that includes a top $20 \%$ Chinese-populated county) from the top $20 \%$ county (counties) located in that state. Non-Chinese counties in states that do not include a top $20 \%$ Chinese county are not included in the sample. In columns 1 and 3, LN(DIST) is the logarithm of the simple average distance, while in columns 2 and 4 , it is the logarithm of the weighted average distance (in kilometers), where the weight is the number of Chinese in the top Chinese counties in the state. The dependent variable is the county-level annual nominal housing price growth. POST is a post-event dummy that has a value of 1 if it is in 1998 (2012) or after for the 1997 (2011) event, and 0 otherwise. PIGOY is the contemporaneous county-level annual nominal personal income growth. POPGOY is the contemporaneous county-level annual population growth. FUTURE_PIG5Y is the average county-level nominal personal income growth of the next 5 years or the remaining years for which data are available. FUTURE POPG5Y is the average county-level population growth of the next 5 years or the remaining years for which data are available. State interacted with year fixed effects are included. The robust standard errors are based on clustering at the county-level. Estimated coefficients and the robust standard errors (in parentheses) are reported. ${ }^{\star \star *}$ indicates the $1 \%$ level of significance.

\begin{tabular}{|c|c|c|c|c|}
\hline \multirow[t]{2}{*}{ Event } & \multicolumn{2}{|c|}{2011} & \multicolumn{2}{|c|}{1997} \\
\hline & $\begin{array}{l}\text { Weighted } \\
\text { Average }\end{array}$ & $\begin{array}{l}\text { Simple } \\
\text { Average }\end{array}$ & $\begin{array}{l}\text { Weighted } \\
\text { Average }\end{array}$ & $\begin{array}{l}\text { Simple } \\
\text { Average }\end{array}$ \\
\hline $\begin{array}{c}\text { Distance From Top 20\% } \\
\text { Chinese-Populated Counties (DIST) }\end{array}$ & 1 & 2 & 3 & 4 \\
\hline POST × LN(DIST) & $\begin{array}{l}-0.030^{\star \star \star} \\
(0.002)\end{array}$ & $\begin{array}{l}-0.030^{\star \star \star} \\
(0.002)\end{array}$ & $\begin{array}{l}-0.010^{\star \star \star} \\
(0.001)\end{array}$ & $\begin{array}{l}-0.010^{\star \star \star} \\
(0.001)\end{array}$ \\
\hline LN(DIST) & $\begin{array}{l}0.022^{\star \star \star} \\
(0.001)\end{array}$ & $\begin{array}{l}0.023^{\star \star \star} \\
(0.001)\end{array}$ & $\begin{array}{l}0.004^{\star \star \star} \\
(0.001)\end{array}$ & $\begin{array}{l}0.003^{\star \star \star} \\
(0.001)\end{array}$ \\
\hline PIGOY & $\begin{array}{l}0.066^{\star \star \star} \\
(0.016)\end{array}$ & $\begin{array}{l}0.066^{\star \star \star} \\
(0.016)\end{array}$ & $\begin{array}{l}0.075^{\star \star \star} \\
(0.020)\end{array}$ & $\begin{array}{l}0.075^{\star \star \star} \\
(0.020)\end{array}$ \\
\hline POPGOY & $\begin{array}{l}0.362^{\star \star \star} \\
(0.063)\end{array}$ & $\begin{array}{l}0.367^{\star \star \star} \\
(0.063)\end{array}$ & $\begin{array}{l}0.229^{* \star \star} \\
(0.053)\end{array}$ & $\begin{array}{l}0.229^{\star \star \star} \\
(0.053)\end{array}$ \\
\hline FUTURE_PIG5Y & $\begin{array}{l}0.111^{\star \star \star} \\
(0.036)\end{array}$ & $\begin{array}{l}0.110^{\star \star \star} \\
(0.035)\end{array}$ & $\begin{array}{c}0.001 \\
(0.037)\end{array}$ & $\begin{array}{c}0.001 \\
(0.037)\end{array}$ \\
\hline FUTURE_POPG5Y & $\begin{array}{c}-0.138 \\
(0.088)\end{array}$ & $\begin{array}{c}-0.142 \\
(0.088)\end{array}$ & $\begin{array}{c}-0.078 \\
(0.072)\end{array}$ & $\begin{array}{c}-0.081 \\
(0.072)\end{array}$ \\
\hline $\begin{array}{l}\text { No. of obs. } \\
\text { Adj. } R^{2}\end{array}$ & $\begin{array}{l}9,234 \\
0.600\end{array}$ & $\begin{array}{l}9,234 \\
0.601\end{array}$ & $\begin{array}{l}7,439 \\
0.288\end{array}$ & $\begin{array}{l}7,439 \\
0.288\end{array}$ \\
\hline
\end{tabular}

county (in any state that includes a top 20\% Chinese-populated county) from the top $20 \%$ counties located in that state. We construct both a simple average distance as well as a weighted-average distance based on the Chinese population numbers. Non-Chinese counties in states that do not include a top $20 \%$ Chinese county are not included in the sample. Table 9 reports results for regressions that include state $\times$ year fixed effects. The coefficient of the interaction of POST and the logarithm of average distance (weighted-average distance) is significantly negative, suggesting that the spillover effect to non-Chinese counties dampens with distance from the counties with a significant Chinese population.

\section{Educational Links and Property Price Growth}

It has been widely reported in the media that Chinese families that have sent children to study abroad have invested heavily in the residential markets of these countries (see, e.g., Bradsher and Searcey (2015) and Juwai (2016)). They do so partly as an investment to finance their children's education, and also to find a place for them to stay (sometimes both, in separate locations). Moreover, familiarity with a region is likely to develop when they visit their children, and investment in 
residential property could follow. In this section, we examine whether such educational links determine the destinations of capital outflows from China and affect the residential prices in these regions.

Our annual international student enrolment data is for the USA as a whole, and begins in the year 1999. However, to capture the strength of educational links, we rank states based on international student numbers in these states as of 2017. We then estimate the following model separately for the top and bottom third of hosting states based on international student numbers in 2017. ${ }^{24}$ For 2000-2016, we estimate the following model:

$$
\begin{aligned}
\overline{\mathrm{HPG}}_{\mathrm{HC}, s, t}-\overline{\mathrm{HPG}}_{\mathrm{LC}, s, t}= & a+b \times \Delta \mathrm{CHINSTU}_{t}+c \times \Delta \mathrm{NCHINSTU}_{t}+d \\
& \times\left(\overline{X_{\mathrm{HC}, s, t}}-\overline{X_{\mathrm{LC}, s, t}}\right)+\gamma_{s}+\epsilon_{s, t} .
\end{aligned}
$$

For the 2011 event, we estimate the following model:

$$
\begin{aligned}
\overline{\mathrm{HPG}}_{\mathrm{HC}, s, t}-\overline{\mathrm{HPG}}_{\mathrm{LC}, s, t} \\
=a+b \times \mathrm{POST}+c \times \Delta \mathrm{CHINSTU}_{t} \times \mathrm{POST}+d \times \Delta \mathrm{NCHINSTU}_{t} \\
\quad \times \mathrm{POST}+e \times \Delta \mathrm{CHINSTU}_{t}+f \times \Delta \mathrm{NCHINSTU}_{t}+g \\
\quad \times\left(\overline{X_{\mathrm{HC}, s, t}}-\overline{X_{\mathrm{LC}, s, t}}\right)+\gamma_{s}+\epsilon_{s, t} .
\end{aligned}
$$

Here, the dependent variable is the difference in the average housing price growth in above-median (HC) and below-median (LC) Chinese-populated MSAs in state $s$ in each quarter. $\triangle$ CHINSTU $_{t}$ is the change in the number of Chinese international students in the U.S, in the year corresponding to quarter $t$, and $\triangle$ NCHINSTU $_{t}$ is the change in the number of non-Chinese international students. POST is an indicator variable equal to 1 for any of the quarters after the eventquarter (2011:Q2), and 0 otherwise. The regressions control for the difference in the average of MSA-level economic variables between above-median and belowmedian Chinese-populated MSAs in state $s$, well as state fixed effects.

We are restricted to the 2011 event because international student data is not available for the early 1990s. We also estimate reduced-form regressions with RPR replacing POST in equation (4).

We expect that the impact of an increase in student numbers would be mainly confined to the more important hosting states, and within these states, if Chinese capital inflows and investment in residential property follow Chinese international students, then they are more likely to be invested in MSAs with higher Chinese population that in those with lower Chinese population within those states. We consider the top and bottom third of hosting states. For equation (3), we expect the

\footnotetext{
${ }^{24}$ In the Supplementary Material, List 4 in Table OA1 gives the 2017 international student numbers for each state. We obtain the state-level international student numbers from the Institute of International Education and the country-level yearly total and Chinese international student numbers from UNESCO Institute of Statistics. The annual change in the number of the non-Chinese international students $\left(\triangle \mathrm{NCHINSTU}_{t}\right)$ is the change in the difference between the total and Chinese international student numbers from year $t-1$ to year $t$.
} 
coefficient of the change in Chinese student numbers to be positive and significant for the top third of hosting states, but not for the bottom third of hosting states. Further, the inflow of Chinese capital per student should be higher after the 2011

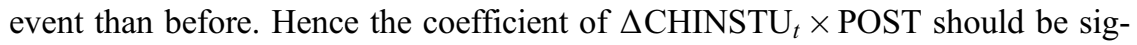
nificantly positive for the top third of hosting states. Similarly, in our reduced-form regressions for 2000-2016, the coefficient of $\Delta \mathrm{CHINSTU}_{t} \times \mathrm{RPR}$ should be significantly positive.

The results reported in the first 2 columns of Table 10 show that, for the top third of hosting states, the change in the number of Chinese international students in the USA has a significantly positive effect on the difference in property price

\title{
TABLE 10
}

\section{Chinese Student Inflows and U.S. Housing Prices}

\begin{abstract}
In column 1 [2-4] of Table 10, the sample consists of the bottom [top] third of hosting states, in terms of the 2017 foreign student number. For the 2011 event, the sample period is 2006:Q2-2016:Q2, excluding the event quarter. For each state, we partition its MSAs into 2 groups - high and low Chinese population - based on the median 2010 MSA-level Chinese population. The dependent variable is the difference in average real MSA quarterly housing price growth between the high and low Chinese groups. $\triangle$ CHINSTU ( $\triangle$ NCHINSTU) is the change in the number of the Chinese (non-Chinese) international students in the USA, in millions, from the previous calendar year to the current calendar year. POST is a post-event dummy for the 2011 event that has a value of 1 if it is in 2011:Q3 or after, and 0 otherwise. RPR is China's political risk relative to the USA based on ICRG political risk ratings of the previous calendar year. $\triangle$ RPIGOY is the difference in the average contemporaneous real MSA personal income growth of the current calendar year between the high and low Chinese groups. $P$ POPGOY is the difference in the average contemporaneous MSA population growth of the current calendar year between the high and low Chinese groups. FUTURE_ARPIG5Y is the average $\triangle P R I G$ of the next 5 calendar years or remaining years for which data are available. FUTURE_APOPG5Y is the average $\triangle P O P G$ of the next 5 calendar years or remaining years for which data are available. State fixed effects are included. Estimated coefficients and the robust standard errors (in parentheses) are reported. ${ }^{\star \star \star}$ and ${ }^{\star *}$
\end{abstract} indicate the $1 \%$ and $5 \%$ levels of significance, respectively.

\begin{tabular}{|c|c|c|c|c|}
\hline \multirow[t]{2}{*}{ Hosting States } & \multirow{2}{*}{$\frac{\text { Bottom } 1 / 3}{2000-2016}$} & \multicolumn{3}{|c|}{ Top $1 / 3$} \\
\hline & & 2000-2016 & 2011 Event & 2000-2016 \\
\hline Sample Period & 1 & 2 & 3 & 4 \\
\hline$\Delta \mathrm{CHINSTU}$ & $\begin{array}{c}0.031 \\
(0.026)\end{array}$ & $\begin{array}{l}0.059^{\star \star \star} \\
(0.010)\end{array}$ & $\begin{array}{l}0.069^{\star \star *} \\
(0.025)\end{array}$ & $\begin{array}{c}-0.366^{\star \star} \\
(0.144)\end{array}$ \\
\hline$\triangle \mathrm{NCHINSTU}$ & $\begin{array}{c}0.000 \\
(0.013)\end{array}$ & $\begin{array}{l}0.030^{\star \star \star} \\
(0.004)\end{array}$ & $\begin{array}{l}0.080^{* * *} \\
(0.025)\end{array}$ & $\begin{array}{l}0.304^{\star \star \star} \\
(0.101)\end{array}$ \\
\hline POST $\times \Delta$ CHINSTU & & & $\begin{array}{l}0.154^{\approx * \star \star \star} \\
(0.063)\end{array}$ & \\
\hline POST $\times \triangle \mathrm{NCHINSTU}$ & & & $\begin{array}{c}-0.019 \\
(0.031)\end{array}$ & \\
\hline POST & & & $\begin{array}{c}-0.003 \\
(0.002)\end{array}$ & \\
\hline RPR $\times \triangle$ CHINSTU & & & & $\begin{array}{l}0.285^{\star \star \star} \\
(0.110)\end{array}$ \\
\hline $\mathrm{RPR} \times \triangle \mathrm{NCHINSTU}$ & & & & $\begin{array}{c}-0.217^{\star \star \star} \\
(0.073)\end{array}$ \\
\hline RPR & & & & $\begin{array}{l}0.012^{\star \star \star} \\
(0.002)\end{array}$ \\
\hline$\triangle$ RPIGOY & $\begin{array}{l}0.065^{\star \star \star} \\
(0.021)\end{array}$ & $\begin{array}{c}0.005 \\
(0.012)\end{array}$ & $\begin{array}{c}0.007 \\
(0.014)\end{array}$ & $\begin{array}{c}-0.004 \\
(0.012)\end{array}$ \\
\hline$\triangle P O P G O Y$ & $\begin{array}{l}0.193^{\star \star \star} \\
(0.066)\end{array}$ & $\begin{array}{l}0.094^{\star \star \star} \\
(0.030)\end{array}$ & $\begin{array}{c}0.011 \\
(0.030)\end{array}$ & $\begin{array}{c}0.032 \\
(0.030)\end{array}$ \\
\hline FUTURE_ARPIG5Y & $\begin{array}{l}0.160^{\star \star \star} \\
(0.054)\end{array}$ & $\begin{array}{c}-0.014 \\
(0.024)\end{array}$ & $\begin{array}{c}-0.160^{* * *} \\
(0.034)\end{array}$ & $\begin{array}{l}-0.067^{\star \star \star} \\
(0.023)\end{array}$ \\
\hline FUTURE_APOPG5Y & $\begin{array}{c}0.072 \\
(0.097)\end{array}$ & $\begin{array}{l}0.123^{\star \star} \\
(0.052)\end{array}$ & $\begin{array}{l}0.218^{\star * *} \\
(0.076)\end{array}$ & $\begin{array}{l}0.130^{\star \star \star} \\
(0.050)\end{array}$ \\
\hline CONSTANT & $\begin{array}{c}-0.001 \\
(0.001)\end{array}$ & $\begin{array}{c}-0.001^{\star \star \star} \\
(0.000)\end{array}$ & $\begin{array}{c}-0.003^{* \star *} \\
(0.001)\end{array}$ & $\begin{array}{l}-0.015^{\star \star \star} \\
(0.002)\end{array}$ \\
\hline $\begin{array}{l}\text { No. of obs. } \\
\text { Adj. } R^{2}\end{array}$ & $\begin{array}{c}496 \\
0.0913\end{array}$ & $\begin{array}{l}1,116 \\
0.140\end{array}$ & $\begin{array}{r}720 \\
0.284 \\
\end{array}$ & $\begin{array}{l}1,054 \\
0.193\end{array}$ \\
\hline
\end{tabular}


increase between high and low Chinese MSAs. There is also a similar positive effect of the change in the number of non-Chinese international students in the USA; however, the corresponding coefficient is about 50\% lower. We find no effect for the bottom third of hosting states. In column 3, we examine whether the effect of the change in the number of Chinese international students (for the top third of hosting states) is stronger in the post-2011:Q2 period than the period before. We find that this is indeed the case. The post-period effect associated with a change in Chinese student numbers is slightly more than twice that of the pre-period effect. However, we find no such effect in the post-2011 period associated with the inflow of nonChinese international students. Similarly, in column 4, we find that when RPR is higher, the inflow of Chinese international students has a significantly larger effect on the difference in property prices of above-median and below-median Chinesepopulated MSAs for the top third of hosting states. We find no significant results when we repeat the exercises in the last 2 columns on the bottom third of hosting states (these results are not reported).

\section{Evidence From Global Cities}

Our results discussed above are for U.S. residential property markets. However, Chinese capital flight is likely to reach other countries as well, although precise magnitudes are not readily available. Indeed, media reports suggest that Chinese investors have been making significant investments in the real estate markets of countries like the U.K., Canada, and Australia. While in the USA, Chinese investment in real estate has been associated with surging residential housing markets in San Francisco and Los Angeles, similar associations have been observed for other global cities. In this section, we extend our event-based and relative political-risk-based analysis to examine the effect of Chinese capital inflow on a cross-section of global metropolitan cities. Such an exercise not only gives a clearer picture of the overall impact of CINFC on global property prices, but also serves to strengthen the plausibility and to establish the external validity of our analysis of U.S. residential property markets.

While we do not have a snapshot of Chinese population distribution from a single source for regions outside the USA to do tests similar to those for the USA, we do have more reliable data on annual population inflow, including Chinese population inflow, as well as on international (including Chinese) student inflow, to various countries for 2000-2017. ${ }^{25}$ However, this data availability restricts us to a shorter time period and to the 2011 event.

We use the ratio of Chinese population inflow to total population inflow to a country in a calendar year as an indicator of the destination of capital outflow from China. The flow data is at the country-level, but our property price data are for major global cities. We calculate the median of the quarterly housing price growth of all cities for each country-quarter as the dependent variable of interest. ${ }^{26} \mathrm{We}$ run

\footnotetext{
${ }^{25}$ Canada and the USA have data as early as 1980 . However, comprehensive coverage of countries begins in 2000 .

${ }^{26}$ The results are essentially the same when we replace the median by the mean or by the mostpopulated city.
} 
weighted least square (WLS) regressions to adjust for the fact that the influence of a population inflow at the country-level will be more relevant for its major cities if the population size in the country is smaller.

There are several concerns with the use of population flow data. One is that because capital and population flows are likely to be highly correlated, it may not be straightforward to discern the effect of capital inflow on property prices from that of population inflow. A related concern is that population flow could be endogenous to country-wide factors that drive city property prices and at the same time attract Chinese and other population groups. To address such concerns, we examine whether the effect of Chinese population inflow (relative to overall population inflow) on major cities' property prices becomes stronger after the 2011 event. The idea is that variation in the proportion of incoming Chinese to a country would be more strongly related to variation in residential prices when capital flight - and per capita capital inflow from China - increases after the 2011 event. To absorb any country-specific metropolis-level factors that could affect property price growth before and after 2011 differently, we include in our regression specification country interacted with post-2011 and pre-2011 dummy fixed effects. Thus, we test whether within-country yearly fluctuation in the ratio of Chinese population inflow to total population inflow has a stronger effect on city property prices in the post-2011 period compared to the pre-2011 period, relative to the mean property price growth in each subperiod. We expect an interaction of a post-2011: Q2 indicator variable and relative Chinese population inflow to have a positive and significant effect on quarterly city property price growth.

The results for this regression are in column 1 of Table 11 . We report WLS regression results, where the weight is the inverse of a country's yearly urban population, obtained from the World Bank. We include among our independent variables contemporaneous GDP growth of the country as well as GDP growth over the next 20 quarters, to control for future expectations of growth affecting property prices. Both variables have significantly positive effects. The main variable of interest - the interaction of the logarithm of the ratio of Chinese population inflow to total population inflow to a country in which a city is located and an indicator variable for the post-2011 period - has a positive and significant coefficient in both regressions. ${ }^{27}$ The coefficient indicates that the increase in the city property price growth is $1 \%$ per quarter in the post-2011 period when the relative Chinese population inflow increases by $1 \%$, compared with that in the pre-2011 period.

In columns 2-4, HCHPINF is an indicator variable that takes the value of 1 if Chinese population inflow as a proportion of overall population inflow to the country to which a city belongs is in the upper $x$ fraction of all countries in our sample for that year, and 0 if it is in the lowest $\mathrm{x}$ fraction, where $x=1 / 2$ in column 2 , $1 / 3$ in column 3 , and $1 / 5$ in column 4 . The key variable of interest is the interaction of HCHPINF and RPR ${ }_{c}$, where the latter variable represents the relative political risk of China and the country in which the city is located. WLS estimates indicate that the coefficient of $\mathrm{HCHPINF} \times \mathrm{RPR}_{c}$ is significantly positive in all columns, and it monotonically increases from column 2 to 4 as the difference between HCHPINF $=1$

\footnotetext{
${ }^{27}$ We consider the logarithm of the relative Chinese population inflow to reduce the impact of skewness of the distribution.
} 
The dependent variable in Table 11 is the median of the quarterly housing price growth of all major cities of a country. In columns 1 and 5, the sample period covers 2006:Q2-2016:Q2, but excludes 2011:Q2. In columns 2-4, the sample period is 2000-2016. POST is a post-event dummy that has a value of 1 for 2011:Q3 or after, and 0 for the other quarters. CHPINF (CHSTUINF) is the logarithm of the ratio of a country's contemporaneous annual Chinese population (student) inflow to overall foreign (foreign student) inflow. The sample in columns $2-4$ consists of the extreme top and bottom $x$ of CHINF (by year), where $x=1 / 2,1 / 3$, and $1 / 5$, respectively. HCHPINF has a value of 1 for countries in the top $x$, and 0 for countries in the bottom $x$. RPR $C$ is China's political risk relative to country $C$ in which a city is located, based on ICRG political risk ratings of the previous calendar year. GDPGOQ is the contemporaneous quarterly GDP growth of the country. FUTURE_GDPG20Q is the countrylevel average GDP growth of the next 20 quarters or remaining quarters for which data are available. In columns 1 and 5 , country fixed effects interacted with POST and country fixed effects interacted with (1-POST) are included. In columns $2-4$, country fixed effects are included. The robust standard errors are based on clustering at the quarter level. This table reports the results of the weighted least square regressions, where the inverse of the contemporaneous annual country-level urban population is the weight in columns 1-4 and the contemporaneous annual country-level ratio of the total foreign student number to the urban population is the weight in column 5 . Estimated coefficients and the robust standard errors (in parentheses) are reported. ${ }^{\star \star \star},{ }^{\star \star}$, and * indicate the 1\%,5\%, and $10 \%$ levels of significance, respectively.

\begin{tabular}{|c|c|c|c|c|c|}
\hline & \multicolumn{5}{|c|}{ Extreme $x \%$ Chinese Inflow by Proportion } \\
\hline & - & $x=1 / 2$ & $x=1 / 3$ & $x=1 / 5$ & - \\
\hline & 1 & 2 & 3 & 4 & 5 \\
\hline POST $\times$ CHPINF & $\begin{array}{l}0.010^{\star \star \star} \\
(0.003)\end{array}$ & & & & \\
\hline CHPINF & $\begin{array}{c}-0.006^{\star \star} \\
(0.003)\end{array}$ & & & & \\
\hline $\mathrm{RPR}_{C} \times \mathrm{HCHPINF}$ & & $\begin{array}{l}0.016^{\star \star} \\
(0.007)\end{array}$ & $\begin{array}{l}0.044^{\star \star \star} \\
(0.010)\end{array}$ & $\begin{array}{l}0.055^{\star \star \star} \\
(0.011)\end{array}$ & \\
\hline $\mathrm{RPR}_{C}$ & & $\begin{array}{c}0.002 \\
(0.027)\end{array}$ & $\begin{array}{c}0.001 \\
(0.024)\end{array}$ & $\begin{array}{c}0.020 \\
(0.025)\end{array}$ & \\
\hline POST $\times$ CHSTUINF & & & & & $\begin{array}{l}0.016^{\star \star \star} \\
(0.004)\end{array}$ \\
\hline CHSTUINF & & & & & $\begin{array}{c}0.004^{\star} \\
(0.002)\end{array}$ \\
\hline GDPGOQ & $\begin{array}{l}0.630^{\star \star \star} \\
(0.157)\end{array}$ & $\begin{array}{l}0.456^{\star \star \star} \\
(0.142)\end{array}$ & $\begin{array}{l}0.218^{* *} \\
(0.099)\end{array}$ & $\begin{array}{l}0.416^{\star \star} \\
(0.160)\end{array}$ & $\begin{array}{l}0.669^{\star \star \star} \\
(0.119)\end{array}$ \\
\hline FUTURE_GDPG20Q & $\begin{array}{l}1.556^{\star \star} \\
(0.714)\end{array}$ & $\begin{array}{r}1.041^{*} \\
(0.524)\end{array}$ & $\begin{array}{c}0.639 \\
(0.554)\end{array}$ & $\begin{array}{l}1.674^{\star \star} \\
(0.655)\end{array}$ & $\begin{array}{l}1.214^{\star \star} \\
(0.467)\end{array}$ \\
\hline $\begin{array}{l}\text { No. of obs. } \\
R^{2}\end{array}$ & $\begin{array}{l}1,010 \\
0.234\end{array}$ & $\begin{array}{l}1,522 \\
0.162\end{array}$ & $\begin{array}{l}1,016 \\
0.253\end{array}$ & $\begin{array}{r}669 \\
0.353\end{array}$ & $\begin{array}{c}1036 \\
0.260\end{array}$ \\
\hline
\end{tabular}

and HCHPINF $=0$ widens. This evidence suggests that when Chinese capital inflows increase, major city residential prices increase more in countries that attract more Chinese.

Finally, we examine whether Chinese student inflows affect property prices in global cities, using the international student inflow data for the countries in which the cities are located. However, since we do not have data on Chinese population distribution within regions in a country, we do not conduct a withincountry comparison between high and low Chinese-populated regions as we do for the USA. Instead, we follow the same approach as that for our analysis of Chinese population inflow. In a regression specification identical to that reported in column 1 of Table 11, we replace the yearly country-level ratio of Chinese population inflow to total population inflow with the yearly country-level ratio of Chinese student inflow to total foreign student inflow.

Column 5 of Table 11 reports WLS regression results. The weight of the WLS is the yearly country-level ratio of total foreign student inflow to the total urban population. The results are qualitatively the same as those for Chinese population inflow. The key variable of interest - the interaction of relative Chinese student inflow and an indicator variable for the post-2011 period - has a significantly 
TABLE 12

Chinese Capital and Population Inflows and Employment Growth in Global Metropolitan Areas

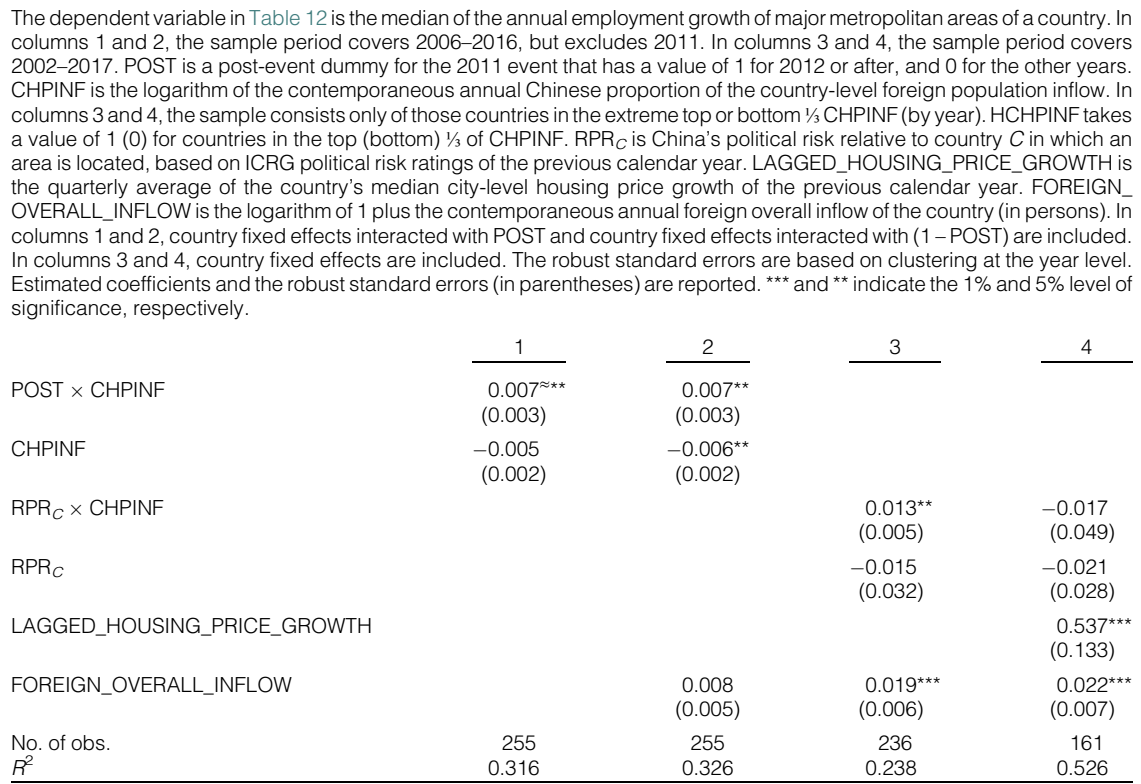

positive coefficient in both regressions. In particular, when the relative Chinese student inflow increases by $1 \%$, the growth of the global city property prices increases $1.6 \%$ per quarter in the post-event period. It is worth noting that the uninteracted Chinese student inflow is also positive and statistically significant at the $10 \%$ level, suggesting the existence of a positive effect on the global city housing price growth before the 2011 event.

In Table 12, we examine the association of Chinese capital inflow and employment growth in metropolitan areas of a country. The specifications in columns 1 and 2 are similar to that in column 1 of Table 11, and include country fixed effects interacted with POST and 1-POST. We find that the interaction of the proportion of Chinese population inflow to total population inflow and POST is positive and significant after the 2011 event, suggesting that more capital inflow per capita increases metropolitan employment after the 2011 event. ${ }^{28}$ In columns 3 and 4 , we report reduced-form regressions. HCHINF is an indicator variable that takes the value of 1 if the proportion of Chinese population inflow to overall population inflow is in the top third of all countries for which we have data, and 0 if it is in the bottom third. Countries in the middle third are dropped. The interaction of HCHINF and $\mathrm{RPR}_{c}$ is significantly positive in column 3 . However, it becomes insignificant in column 4 when we control for lagged residential price growth, consistent with

\footnotetext{
${ }^{28}$ The magnitude of the effect on employment $(0.007)$ in relation to that on housing $(0.010)$ for our global samples is highly comparable to that $(0.011$ and 0.006 , respectively) for our U.S. samples.
} 
our findings in Table 5, suggesting that the capital flow into the housing market is a major driver of the employment growth.

\section{Additional Results}

In this section, we address several issues relating to the robustness of our results.

\section{A. Excluding California}

The state of California is the most Chinese-populated state in the USA, with a Chinese population of 1.185 million as of 2010 , which is about two times greater than that of New York, the second most Chinese-populated state. It is quite possible, therefore, that the state attracts a large share of the Chinese capital inflow to the USA, and the question then arises whether our results hold if we leave California out.

We exclude California and rerun our main regressions. In Table OA2 of the Supplementary Material, we report the coefficient estimates of HCT $\times$ POST for the two events. The coefficient remains statistically significant (except for the within-MSA county regression corresponding to column 1 of Table 7), and the economic magnitudes of the estimated effects of CINFC subsequent to the two events, though somewhat smaller when California is excluded, remain quantitatively important. These results therefore reinforce the results on samples that exclude the top $10 \%$ of Chinese MSAs reported throughout the paper: while California and the major Chinese-populated MSAs seem to contribute significantly to the overall impact of CINFC on U.S. housing prices, the Chinese population in the country is now spread out enough that there are significant effects on other regions as well. ${ }^{29}$

\section{B. Classifications Based on Overall Population and Controlling for Coastal Regions}

For our classification of regions with stronger Chinese ties vs. weaker Chinese ties, we have relied on early Chinese population distributions. However, early population distributions (whether of the Chinese population or the overall U.S. population) are also likely nonrandom, and there could be a concern that regions with a higher early population have some unique advantages that persist in recent times. If this is the case, our results could be affected by selection bias (although as Table 1 shows, the $\mathrm{HCT}=1$ and $\mathrm{HCT}=0$ regions in our sample are essentially similar in terms of many economic characteristics, which mitigates this concern). To determine whether there is any evidence of such selection bias for the overall U.S. population, we classify U.S. MSAs and counties as high total population $(\mathrm{HT}=1)$ and low population $(\mathrm{HT}=0)$ regions based on total population (as of 1880 and 1870, respectively) in the same way as we classify regions based on early Chinese population. The upper panel of Table OA4 in the

\footnotetext{
${ }^{29}$ It is also worth noting that the spillover results documented in Tables 8 and 9 also imply that the effect of CINFC is not confined to counties that have substantially more Chinese population.
} 
Supplementary Material shows that POST $\times$ HT is either of the wrong sign or is insignificant in all but one of the regressions. ${ }^{30}$ The lower panel shows that inclusion of POST $\times$ HT does not have any meaningful effect on the coefficients of POST $\times$ HCT.

Thus, while it is possible that early population distribution across regions is associated with regional characteristics that persist over long periods, for such factors to explain our results this would have to be the case only for regions that were associated with early Chinese settlement. The coastal states in the West and New York in the East experienced significant early Chinese settlement, and it could be argued that coastal states have historically thrived relative to other parts of the country and could be associated with persistent regional effects. ${ }^{31}$

To further explore whether coastal state locations explain some of our remaining results, in Table OA5 we include an interaction term POST $\times$ COAST, where the latter variable is an indicator variable that takes the value of 1 for an MSA or county located in a coastal state, and 0 otherwise. For the county-level regressions in the middle 2 columns, instead of within-MSA results, we report results for county-level regressions analogous to Table 6 using county and year fixed effects. POST $\times$ COAST is significant for housing price growth post-1997 and for employment growth post-2011. However, POST $\times$ HCT remains positive, with almost the same magnitude, and significant in all regressions.

\section{Supply Elasticities}

Property prices may respond more to capital inflows to residential markets or other demand shocks if supply elasticities are lower. It is possible that HCT $=1$ regions are associated with tighter regulation of residential construction relative to $\mathrm{HCT}=0$ regions. To determine whether this could be driving our results, we rerun our main housing regressions by additionally controlling for a composite regulatory index (LURI). LURI is a standardized measure of residential land use regulatory restrictiveness, based on a 2018 survey of communities across nationwide metropolitan areas in the USA. ${ }^{32}$ The index is the first factor of a factor analysis of a dozen subindexes that capture the different components of the local regulatory environment (Gyourko et al. (2019)). The results are reported in Table OA6 of the Supplementary Material. POST $\times$ LURI has positive and significant coefficients for MSA level regressions, suggesting that supply elasticities do contribute toward

\footnotetext{
${ }^{30}$ The exception occurs for the within-MSA county-level property price result for the 1997 event. The upper panel of Table OA3 in the Supplementary Material shows that HT $=1$ regions have higher Chinese population and percentage of Chinese than $\mathrm{HT}=0$ regions, especially for counties. This could potentially explain why, for the within-MSA county-level regressions, residential prices increase more for the 1997 event for HT = 1 counties than for HT = 0 counties (recall that, consistent with spillover, the within-MSA results are stronger for high Chinese counties for the 1997 event as well, compared to the 2011 event).

${ }^{31}$ However, it is worth noting that our within-MSA county-level results in Table 7, our within-state results based on educational links in Table 10, and those for global metropolitan cities in Tables 11 and 12, cannot be attributed to coastal state effects.

${ }^{32}$ Gyourko, Hartley, and Krimmel (2019) report that highly (lightly) regulated housing markets in the 2005 survey do not generally change to be less (more) strictly regulated in the 2018 survey.
} 
the impact of CINFC on residential property prices. However, the coefficients of POST $\times$ HCT remain positive and highly significant in all regressions.

\section{Relative Political Risk Revisited}

In our reduced-form regressions, we used RPR to proxy for CINFC. We choose the level, rather than the change, in RPR because capital flight may not immediately reach an equilibrium level when a major change in RPR occurs. For example, if RPR declines only slightly following a large increase, capital flight is likely to continue. To determine whether our results hold when we accommodate lagged response to significant changes in RPR, we construct a measure of change in risk (CRPR) as the difference between last-period's RPR and the mean RPR of the previous 3 years. DRPR is a dummy variable that equals 1 when CRPR is above the 90 th percentile in either the current year or the previous year, and 0 otherwise. The results in Table OA7 of the Supplementary Material show that the interaction of DRPR and HCT is significant in our main specifications. Results are similar when we extend DRPR to cover 1 more year.

\section{E. Imputed CINFC}

As discussed above, we validate our results using imputed CINFC (ICINFC). Figure 2 shows this series, and in Table OA 8 of the Supplementary Material, we replicate our main results based on ICINFC. The interactions of ICINFC and HCT are positive and significant.

\section{F. Synthetic Matching}

We also replicate our main results for the USA on synthetically matched samples of $\mathrm{HCT}=1$ and $\mathrm{HCT}=0 \mathrm{MSAs}$ and counties. These results are reported in Table OA9 of the Supplementary Material. ${ }^{33}$ Our main conclusions are unchanged.

\section{Conclusion}

Kar and LeBlanc (2013) document that China has by far the largest accumulated capital flight among the top 15 developing countries over the past two decades. Anecdotal evidence suggests that a significant part of capital outflows from China has been invested in residential property markets in the developed world and has contributed to property price appreciation in these markets. However, there is little academic research on these issues, and not enough is known about whether the impact of capital inflows from China on property prices in foreign residential markets is quantitively important, and if so, whether such

\footnotetext{
${ }^{33}$ The synthetic control method creates a synthetic version of treated units by weighting variables and observations in the control group. In other words, a synthetic control MSA, which does not necessarily exist, is a weighted average of various MSAs in the control group. We explain this method with reference to the MSA housing analysis. For each treated MSA (MSA with HCT $=1$ ), the synthetic control MSA is formed by searching for a weighted average of MSAs in the control group (with HCT $=0$ ) whose predicted housing price growth over the pre-event period, based on our MSA housing model, is the closest match to that of the treated MSA. See Abadie, Diamond, and Hainmueller (2015).
} 
effects are confined to regions that historically have high concentration of Chinese immigrants. Even less is known about the possible impacts of Chinese capital inflows on the level of economic activity of these regions, and the channels through which such effects might operate.

We attempt to provide some answers to these questions. Available evidence indicates that capital flight from China increases when political risk in China increases relative to that in other countries (e.g., after 1997 following Deng Xiaoping's death), and then more substantially after the bursting of the property bubble in China in 2011 and the launch of Xi Jinping's anti-corruption drive soon thereafter. Absent comprehensive data on the exact magnitude or destinations of such capital outflows, it has been hard to establish the potential impact of outflows on international property markets. We assess the impact of Chinese capital flight on foreign residential markets by examining whether residential property prices and real economic activity are more affected in regions with stronger ethnic and student links to China when China's political risk increases. While we focus mainly on U.S. regions, we also study global metropolitan areas. Our results confirm that ethnic and educational links play an important role in determining the destinations of the Chinese capital outflows and their impact on foreign residential property markets and the associated local economies. The effects are economically significant, and not limited, e.g., to the coastal areas in the USA, or the state of California. We document spillover effects to nearby regions that do not have strong ethnic ties and are thus unlikely to be a destination of Chinese capital flight. These effects are also present in major cities worldwide. The local economies of regions that attract inflows of Chinese capital experience significantly higher employment growth and bank deposit growth. Our results suggest that the real estate sector plays an important role in boosting employment growth, but a less important role in boosting deposit growth.

\section{Supplementary Material}

To view supplementary material for this article, please visit http://doi.org/ 10.1017/S0022109022000072.

\section{References}

Abadie, A.; A. Diamond; and J. Hainmueller. "Comparative Politics and the Synthetic Control Method." American Journal of Political Science, 59 (2015), 495-510.

Agarwal, S.; H. S. Choi; J. He; and T. F. Sing. "Matching in Housing Markets: The Role of Ethnic Social Networks." Review of Financial Studies, 32 (2019), 3958-4004.

Badarinza, C., and T. Ramadorai. "Home Away from Home? Foreign Demand and London House Prices.” Journal of Financial Economics, 130 (2018), 532-555.

Bradsher, K., and D. Searcey. "Chinese Cash Floods U.S. Real Estate Market." The New York Times, Nov. 29, available at http://www.nytimes.com/2015/11/29/business/international/chinese-cashfloods-us-real-estate-market.html? $\mathrm{r}=0$ (2015).

Cheung, Y. W., and X. Qian. "Capital Flight: China's Experience.” Review of Development Economics, 14 (2010), 227-247.

Cheung, Y. W.; S. Steinkamp; and F. Westermann. "China's Capital Flight: Pre-and Post-Crisis Experiences.” Journal of International Money and Finance, 66 (2016), 88-112.

Cuddington, J. T. "Capital Flight: Estimates, Issues and Explanations." In Princeton Studies in International Finance. Princeton, NJ: Princeton University (1986), 58. 
Favilukis, J. Y., and S. Van Nieuwerburgh. "Out-of-Town Home Buyers and City Welfare." Journal of Finance, 76 (2021), 2577-2638.

Ferrantino, M. J.; X. Liu; and Z. Wang. "Evasion Behaviors of Exporters and Importers: Evidence from the US-China Trade Data Discrepancy." Journal of International Economics, 86 (2012), 141-157.

Gunter, F. R. "Capital Flight from China: 1984-2001.” China Economic Review, 15 (2004), 63-85.

Gunter, F. R. "Capital Flight." In International Encyclopedia of the Social Sciences, 2nd edn., W. A. Darity Jr., ed. Detroit: Macmillan Reference (2008), 434-436.

Gunter, F. R. "Corruption, Costs, and Family: Chinese Capital Flight, 1984-2014." China Economic Review, 43 (2017), 105-117.

Gyourko, J.; J. Hartley; and J. Krimmel. "The Local Residential Land Use Regulatory Environment Across U.S. Housing Markets: Evidence from a New Wharton Index." National Bureau of Economic Research, No. w26573 (2019).

Juwai. "6 Reasons Why Education Underpins Chinese Overseas Property Investment." July 7, available at https://ist.juwai.com/news/2016/07/6-reasons-why-education-underpins-chinese-overseasproperty-investment (2016).

Kar, D., and B. LeBlanc. Illicit Financial Flows from Developing Countries: 2002-2011. Washington, DC: Global Financial Integrity (2013).

Kar, D., and J. Spanjers. Illicit Financial Flows from Developing Countries: 2003-2012. Washington, DC: Global Financial Integrity (2014).

Li, Z.; L. S. Shen; and C. Zhang. "Capital Flows, Asset Prices, and the Real Economy: A 'China Shock' in the US Real Estate Market.” FRB International Finance Discussion Paper 1286 (2020).

Taplin, N. “'Back Door' Capital Outflows Should Worry Beijing.” Wall Street Journal, Oct. 14 (2019).

Wong, A. "China's Current Account: External Rebalancing or Capital Flight?" International Finance Discussion Papers 1208. Board of Governors of the Federal Reserve System (2017). https://doi.org/ 10.17016/IFDP.2017.1208.

Yang, J. "Deposit-Lending Synergies: Evidence from Chinese Students at U.S. Universities." Journal of Financial and Quantitative Analysis, 57 (2022), 1960-1986.

Zhu, A.; C. Li; and G. Epstein. "Chapter 10. Capital Flight from China, 1982-2001." In Capital Flight and Capital Controls in Developing Countries. Cheltenham: Edward Elgar (2005), 262-288. 


\title{
Capital Inflows and Property Prices:
}

Ethnicity, Education, and Spillovers

\author{
Chang, Y-Y
}

2022-02-15

22/04/2023 - Downloaded from MASSEY RESEARCH ONLINE 